July 1979

\title{
WASTER
}

\section{Legal and Institutional Implications of Providing Financial Incentives to Encourage the Development of Solar Technologies}

Richard J. Hyatt
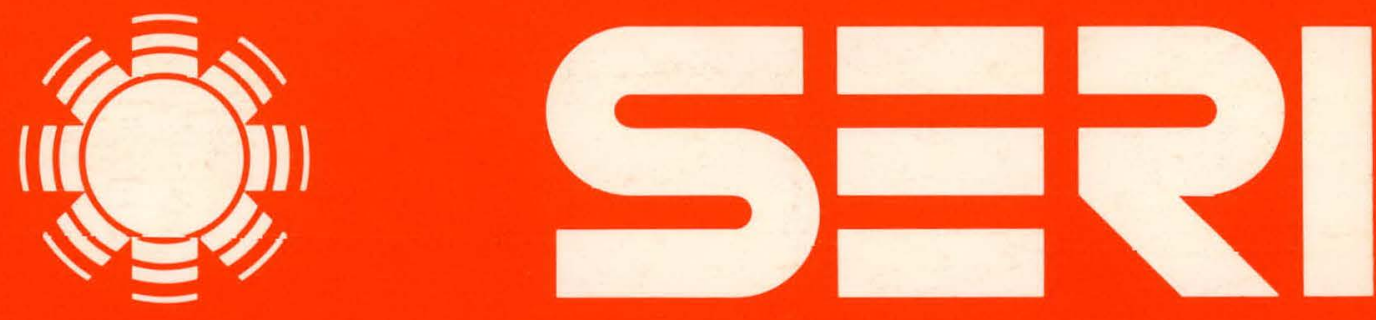

Solar Energy Research Institute A Division of Midwost Research Institute

1536 Cole Boulevard

Golden, Colorado 80401

Operated for the U.S. Department of Energy under Contract No. EG-77-C-01-4042

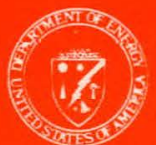




\section{DISCLAIMER}

This report was prepared as an account of work sponsored by an agency of the United States Government. Neither the United States Government nor any agency Thereof, nor any of their employees, makes any warranty, express or implied, or assumes any legal liability or responsibility for the accuracy, completeness, or usefulness of any information, apparatus, product, or process disclosed, or represents that its use would not infringe privately owned rights. Reference herein to any specific commercial product, process, or service by trade name, trademark, manufacturer, or otherwise does not necessarily constitute or imply its endorsement, recommendation, or favoring by the United States Government or any agency thereof. The views and opinions of authors expressed herein do not necessarily state or reflect those of the United States Government or any agency thereof. 


\section{DISCLAIMER}

Portions of this document may be illegible in electronic image products. Images are produced from the best available original document. 


\author{
Printed in the United States of America \\ Available from: \\ National Technical Information Service \\ U.S. Department of Commerce \\ 5285 Port Royal Road \\ Springfield, VA 22161 \\ Price: \\ Microfiche $\$ 3.00$ \\ Printed Copy $\$ 5.25$
}

\title{
NOTICE
}

This report was prepared as an account of work sponsored by the United States Government. Neither the United States nor the United States Department of Energy, nor any of their employees, nor any of their contractors, subcontractors, or their employees, makes any warranty, express or implied, or assumes any legal liability or responsibility for the accuracy, completeness or usefulness of any information, apparatus, product or process disclosed, or represents that its use would not infringe privately owned rights. 
SERI /TR-62-269

UC CATEGORY: UC-59,60,61,62,63,64

MASTER

LEGAL AND INSTITUTIONAL IMPLICATIONS

OF PROVIDING FINANCIAL INCENTIVES TO

ENCOURAGE THE DEVELOPMENT OF

SOLAR TECHNOLOGIES

RICHARD J. HYATT

JULY 1979

This report was prepored as an account of work

This reporn was prepared as an accoun or work

sponsored by the Uniled Stes Covemment. Neither the

Energ, ner any of their employes, Deparment of

Energ, nor any or their employees, nor any of their

contractors, sucontacloss, or their employees, makes

ony warronty. erpress nr implifen. ar assumes any lepal

liability or responsibity for the accuracy, completeness

or usefulness of any information, apparatus, product or

process disclosed, or represents that its use would not

infringe privately owned rights.

Solar Energy Research Institute

1536 Cole Boulevard

Golden, Colorado 80401.

A Division of Midwest Research Institute

Prepared for the

U.S. Department of Energy

Contract No. EG. $77 \cdot \mathrm{C} \cdot 01 \cdot 4042$ 


\section{FOREWORD}

This paper on legal and institutional implications of providing financial incentives to encourage the development of solar technologies was prepared by the Solar Energy Research Institute (SERI) to fulfill, in part, SERI's solar information dissemination function. This paper is part of the Market Development Branch Law Program, which is in turn part of the overall program of the Technology Commercialization Division.

This is the fourth of eight 1978 Summer Law Intern Papers sponsored by the SERI Law Program. The other seven address (1) the impact of the antitrust laws on the commercialization of solar heating and cooling, (2) licensing arrangements and the development of the solar energy industry, (3) problems in the administration of state solar legislation, (4) legal considerations in the development and implementation of biomass energy technologies, (5) state approaches to solar energy incentives, (6) land-use barriers and incentives to the use of solar energy, and (7) utility rates and service polices as potential barriers to the market penetration of decentralized solar technologies. These eight studies are meant to raise and discuss the primary legal issues that are, or will be, generated by the commercialization of solar technologies.

The author of this paper, Richard Hyatt, was a student at the University of Denver Law School while he was participating in the 1978 Summer Law Intern Program. He is currently a third-year law student at the Denver Law School.

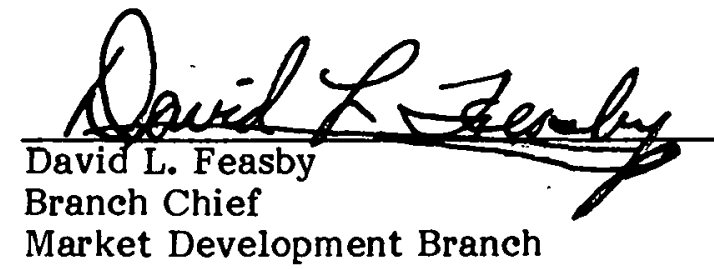

Approved for:

SOLAR ENERGY RESEARCH INSTITUTE

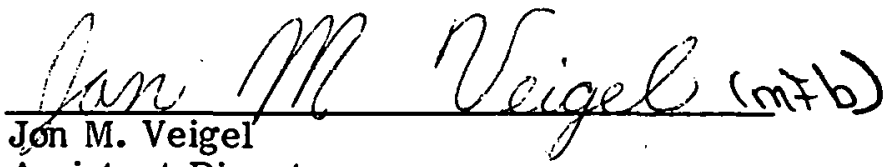

Assistant Director

Technology Commercialization Division 


\section{SUMMARY}

The rapid depletion of nonrenewable sources of energy and the dangerous implications of reliance on foreign sources of energy are causing us to look increasingly toward the sun for a contribution to our energy requirements.

The legal basis to provide financial incentives is found in the enumerated powers of the Constitution for the exercise of federal authority, the police and tax powers for the exercise of state authority, and state delegated powers for the exercise of local authority. These powers are limited by the federal and state constitutions, and the scope of delegated authority.

The major types of financial incentives are tax incentives, including income tax deductions and credits, accelerated depreciation allowances, tax-exempt bonds, and reduction in property and sales taxes; loan incentives, including low interest loans, government guaranteed and insured loans, and elimination of statutory and secondary market constraints; and government transfer incentives, including grants in aid from all levels of government.

Other incentives that will indirectly affect the financing and availability of solar energy technologies include eliminating or reducing financial incentives benefiting competitive energy sources, government action to insure the operation of solar energy equipment, government-sponsored education, research, and development programs, government demonstration and procurement programs, and placing priority on rapid passage of solar energy legislation dealing with financial incentives.

In most cases, a financial incentives program constituting one or more of these incentives will probably not confront any major, unique, legal or institutional impediments. The minor impediments that do exist can usually be eliminated by preventive legislation. 


\section{TABLE OF CONTENTS}

$1.0 \quad$ Introduction $\ldots \ldots \ldots \ldots \ldots \ldots \ldots \ldots \ldots \ldots \ldots \ldots \ldots \ldots \ldots, \ldots \ldots, 1$

2.0 Financial Incentives Benefiting Manufacturers and Purchasers of Capital Intensive Solar Energy Equipment . ................... 3

2.1 Preliminary Considerations . .......................... 3

2.1.1 Sour ces of Federal Authority $\ldots \ldots \ldots \ldots \ldots \ldots \ldots \ldots \ldots \ldots \ldots \ldots \ldots$

2.1.2 Limitations on Federal Authority $\ldots \ldots \ldots \ldots \ldots \ldots \ldots \ldots \ldots \ldots \ldots \ldots$

2.1.3 Sources of State Authority ....................... 5

2.1.4 Limitations on State Authority ..................... 6

2.1.5 Sources of Local Authority ......................... 7

2.1.6 Limitations on Local Authority ...................... 7

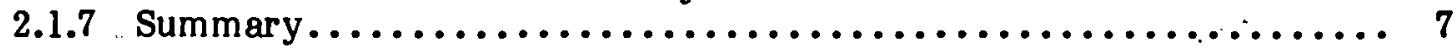

2.2 Tax Incentives $\ldots \ldots \ldots \ldots \ldots \ldots \ldots \ldots \ldots \ldots \ldots \ldots \ldots \ldots \ldots \ldots \ldots \ldots \ldots$

2.2.1 Income Tax Deductions $\ldots \ldots \ldots \ldots \ldots \ldots \ldots \ldots \ldots \ldots \ldots \ldots \ldots \ldots \ldots$

2.2.2 Income Tax Credits............................. 9

2.2.3 Accelerated Depreciation Allowances ................... 11

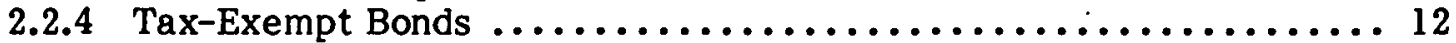

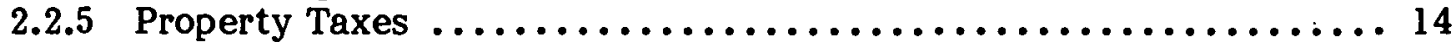

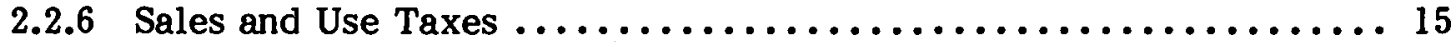

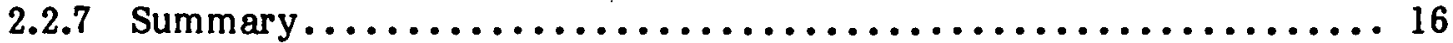

2.3 Loan Incentives $\ldots \ldots \ldots \ldots \ldots \ldots \ldots \ldots \ldots \ldots \ldots \ldots \ldots \ldots \ldots \ldots \ldots \ldots \ldots$

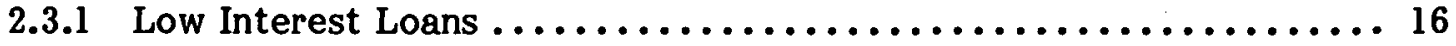

2.3.2 Government Guaranteed and Insured

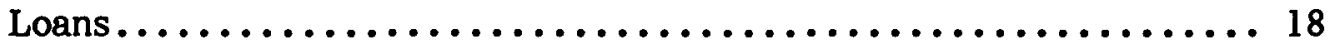

2.3.3 Secondary Market Constraints $\ldots \ldots \ldots \ldots \ldots \ldots \ldots \ldots \ldots \ldots \ldots \ldots \ldots 20$

2.3.4 Statutory Constraints ............................ 21

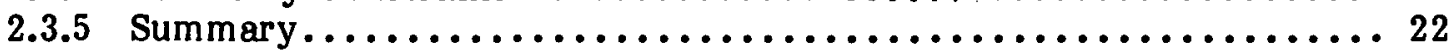

2.4 Government Transfer Incentives......................... 22

2.4 .1 Federal Grants in Aid ............................. 22

2.4.2 State and Local Grants in Aid .......................... 24

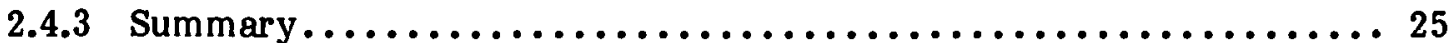

3.0 Government Action Indirectly Affecting the Financing

and Availability of Solar Energy Technologies .................. 27

3.1 Eliminating or Reducing Financial Incentives

Benefiting Competitive Energy Sources ................... 27

3.1.1 Effects of Incentives to Competing

Energy Sources .............................. 27

3.1.2 Financial Incentives to the Oil

Energy Industry ............................. 27

3.1.3 Financial Incentives to the Gas

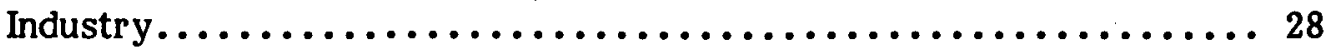

3.1.4 Financial Incentives to the Coal

Industry 
3.1.5 Financial Incentives to the Hydroenergy Industry...................................... 29

3.1.6 Financial Incentives to the Nuclear Energy Industry .............................. 29

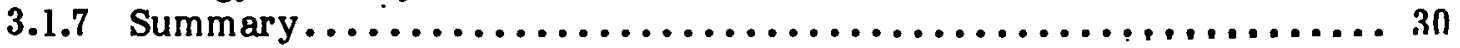

3.2 Government Action to Ensure Operation of Solar Energy Equipment ............................. 30

3.3 Government Sponsored Education, Research, and Development Programs ........................... 31

3.4 Government Demonstration and Prnọırement Progräms '....................................... 31

3.5 Giovernment Financial Incentives as Disincentives

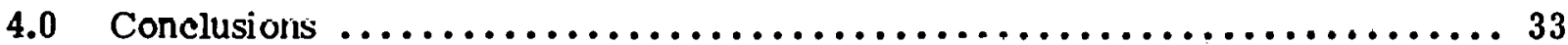

$5.0 \quad$ References...................................... 35 


\section{SECTION 1.0}

\section{INTRODUCTION}

The United States, like all highly mechanized societies, is highly dependent on abundant sources of energy, as was made obvious by the quadrupling of the price of petroleum by the Organization of Petroleum Exporting Countries in the fall of 1973 [1]. Most of our energy is provided by fossil fuels: oil, coal, and natural gas [2]. Oil and coal are also necessary for production of some chemical products. These energy sources are considered finite because world supplies of oil, coal, and natural gas are being dissipated much faster than new supplies are being formed. If these resources become unavailable or exhausted, the transition to new, expensive energy sources could shock our economy severely [3].

The 1973 oil embargo demonstrated the possibility of energy supplies as a political bargaining tool against countries who are dependent on imported sources of energy. In 1976, the United States imported $45 \%$ of its petroleum supplies [4], an extension of great political bargaining power to oil-rich countries. Use of conventional forms of energy is also a major cause of environmental degradation, including air and water pollution, and landscape disruption [5].

Should the United States reappraise its energy needs and sources, the most feasible plan involves conserving and phasing out conventional sources of energy, while developing alternate, preferably renewable, sources of energy. Solar energy seems a likely potential contributor to meeting the nation's energy needs [6].

Solar energy-sunlight-is readily available and virtually inexhaustible. It interacts with the environment in ways which may be exploited to produce usable power [7]. Solar energy includes energy obtained from sunlight concentrated in collectors, energy from biomass and wind, ocean thermal energy conversion, energy from central receiving towers, energy from sunlight reacting with photovoltaic cells, and energy produced by passive technologies.

All new lechnologles face difflculties in acceptance during the early years of commercialization [8]. Solar energy is no exception. The government can hasten acceptance by offering monetary incentives or incentives aimed at eliminating or reducing legal and institutional financial barriers. Policy makers may be concerned about the legal and institutional implications of providing commercialization incentives to industries with which they are not familiar. The purposes of this report are: to identify incentives which policy makers could enact to encourage the development of solar energy technologies, and to discuss possible legal and institutional problems that could thereby arise.

Some simplifying assumptions have been made. First, it is assumed that all solar energy technologies have high initial costs. While this is true for most solar energy technologies, some passive and biomass facilities have reasonable initial costs. It is also assumed that it is possible to differentiate types of solar energy technologies by definition. Finally, it is assumed that policy makers will differentiate the types of solar energy technologies in legislation, making clear the types of systems eligible for the incentives.

Terms in the report such as "solar energy facilities," "solar energy technologies," "solar energy systems," and "solar energy equipment" include all the forms of producing solar energy. The phrase "conventional energy sources" refers to energy produced by oil, natural gas, coal, and hydiojower facilities. 


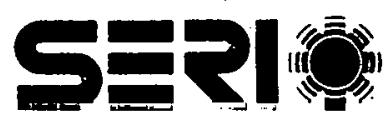




\section{SECTION 2.0}

\section{FWANCIAL WNCENTIVES BENEFTTING MANUFACTURERS AND PURCHASERS OF CAPITAL INTENSIVE SOLAR ENERGY EQUIPMENT}

\subsection{PREIIMINARY CONSIDERATIONS}

If federal, state, and local governments intend to offer financial incentives calculated to benefit the solar energy industry, their actions must have a legal basis. This section reviews the sources of authority available to the three levels of government to induce rapid commercialization of solar energy technologies, and the corresponding limitations on that authority.

\subsubsection{Source of Federal Authority}

The source of authority for federal actions are the enumerated powers delegated to the Federal Government by the Constitution [9]. The three major powers that affect the extension of financial benefits to the solar industry are: the power to regulate interstate commerce [10], the power to tax [11], and the power to spend [12].

The Constitution gives Congress the authority to enact all laws that are "necessary and proper" to regulate the flow of interstate commerce [13]. "[T] he determinative test of the exercise of power by the Congress under the Commerce Clause is simply whether the activity sought to be regulated is 'commerce which concerns more states than one' and has a real and substantial relation to the national interest" [14]. The courts have given Congress the primary responsibility for determining which activities have sufficient influence on interstate commerce to be subject to federal regulation [15].

Solar energy can affect interstate commerce in at least three different ways: (1) component parts of solar energy facilities or the facilities themselves will travel among the states [16]; (2) solar energy may affect the availability and price of energy nationwide [17]; and (3) proliferated use of solar energy will help to achieve other socially desirable federal objectives, such as conservation of conventional sources of energy, decreased reliance on foreign sources of energy, and pollution control [18]. The fact that many solar energy facilities will be small in scale will not result in exemption from federal control as long as the combined effect of these individual operations could have a significant influence on interstate commerce [19].

The classic test for determining which laws are necessary and proper was given by Justice Marshall in McCulloch v. Maryland [20]. "Let the end be legitimate, let it be within the scope of the Constitution, and all means which are appropriate, which are plainly adapted to that end, which are not prohibited, but consist with the letter and spirit of the Constitution, are constitutional" [21]. As long as federal actions are reasonably related to regulating the flow of interstate commerce and the actions do not violate constitutional restrictions, the necessary and proper clause will be satisfied. This gives Congress a great deal of discretion in determining the means with which to effectuate national goals. Financial incentives to accelerate solar commericalization seem an appropriate means of furthering the national goal of energy conservation.

Congress has the power to "lay and collect" taxes and excises "to pay the Debts and provide for the common Defense and general Welfare of the United Statesii [2u]. Like 
the commerce power, this power is plenary and can be used to achieve social welfare objectives [23]. Tax incentives favoring the use of solar energy could be justified under all three of these constitutional purposes. A tax that raises a significant amount of money could be construed as a means to raise revenue to pay the debts of the United States despite the fact that it was enacted to benefit the solar energy industry. A tax encouraging domestic use of solar energy could result in increased availability of conventional energy sources in wartime, thus becoming a tax providing for the common defense. General welfare could encompass most reasons for converting to solar energy, especially since the courts will usually accept legislative determination of what constitutes general welfare. "The discretion belongs to Congress, unless the choice is clearly wrong, a display of arbitrary power, not an exercise of judgment" [24]. Today, the general welfare clause is read to forbid the use of the taxing power for the exclusive benefit of a particular group [25]. Recent cases also suggest that the courts will accept congressional characterization of legislation as a tax, as long as it produces at least some revenue and does not contain provisions extraneous to any tax needs [26].

The spending power has been identified as an implicit grant of authority necessarily arising out of the taxing power, but which is also an independent source of authority, distinct from the taxing power [27]. Nevertheless, this power is subject to the requirements of using the funds collected for paying the debts and providing for the common defense and general welfare. These requirements could also be satisifed as long as the statute spends for solar energy. The major difference between the spending and taxing powers is that the spending power can be used to enact provisions that are extraneous to tax needs [28]. The spending power thus seems a likely source of constitutional authority for solar legislation.

\subsubsection{Limitatons on Federal Authority}

Limitations on the powers of the Federal Government are also found in the Constitution [29]. The major limitations to providing financial incentives benefiting the development of solar energy are found in the Bill of Kights, especially the due process clause and the clause forbidding governmental taking without just compensation, both in the Fif th Amendiment [30].

The due process clause requires that federal statutes and regulations "have a reasonable relation to a proper legislative purpose, and [be] neither arbitrary nor discriminatory" [31]. A financial incentives program for the solar energy industry could be subject to challenge on these grounds. To avoid such a challenge, policy makers should clearly show a substantial relationship between the particular financial incentives enacted and increased utilization of solar energy [32]. A set of procedural safeguards should be implemented to insure public participation and provide against unreasonable administrative regulations [33]. Statutes and regulations should be written in such a manner that a person of ordinary intelligence would have fair notice of forbidden conduct [34]. Regulatory measures cannot contain suspect classifications based on race, alienage, or sex and cannot contain classifications that violate fundamental constitutional rights [35]. Classifications must be reasonably related to a proper governmental objective [36]. Since the development of solar energy seems to be a proper governmental objective, a reasonable classification in federal legislation favoring those people employing solar energy facilities, should survive the due process challenge.

Federal legislation benefiting the solar energy industry and extensively interfering with private property interests may be challenged as a taking of private property without just 
compensation. People who own the capital equipment and raw materials being used to manufacture conventional forms of energy might argue that financial incentives given to the solar energy industry sufficiently reduce the demand for their product to constitute a taking. They would seek compensation to cover the value of their lost profits. "The takings clause is ordinarily not offended by regulation of uses, even though the regulation may severely or even drastically effect the value of the land or real property" [37]. As long as some lower-valued reasonable uses are left to the property owner, no taking occurs [38].

Solar energy incentives probably will not be subject to the takings clause. While an effective financial incentives program will regulate the use of solar energy sufficiently to reduce the demand for conventional sources of energy, conventional sources of energy will still retain a large part of the market. Legislation could constitute a taking because the distinction between regulation and a taking of property has not been developed into a clear formula. Three important factors are: (1) the extent of the loss to the private individual resulting from federal intervention; (2) whether the public gain exceeds the loss to the private individual; and (3) the extent of the private loss beyond the activity that the government sought to control [39]. Since the taking issue has not been raised and litigated in the area of solar energy, these factors should be kept in mind when financial incentives legislation is being fashioned.

\subsubsection{Sources of State Authority}

Those powers not delegated to the Federal Government are reserved by the Constitution to the states. They are the police power [40] and the taxing power [41].

The police power is the inherent authority of a state government to enact laws and regulations that promote public health, safety, and welfare [42]. In the past, the police power has been used to justify implementation of pollution control regulations [43], development of natural resources [44], preservation of exhaustible natural resources [45], and providing heating and cooling in private as well as public buildings [46]. These are a few of the reasons commonly advocated for promoting the development of solar energy technologies [47]. The police power must be used for public purposes, not for encouraging or restraining interests that are exclusively private [48]. The police power is not restricted to the regulation of a certain group of activities, but changes with the needs of society [49]. Expanded use of solar energy today could promote the public health, safety, and welfare [50].

The taxing power is primarily limited to raising revenue, a power indispensable to the existence of any government [51]. Like the police power, it is a grant of power implied from the Constitution [52]. A state can tax only for public purposes; a tax can be levied only if it will promote the general well-being of a society [53]. Well-being on the state level and general welfare on the federal level are the same; differences arise only in the scope and forms of taxation allowed [54]. Courts will usually acquiesce to the legislative determination as to what constitutes a valid public purpose unless the decision is arbitrary or clearly erroneous [55]. Since energy conservation is regarded as promoting the welfare of society, state solar tax measures seem justified. The distinction between the police power and the taxing power is that the police power is exercised for regulatory purposes, while the taxing power is exercised primarily to raise revenue [56]. Even though the powers are distinct, they can and should be used concurrently to effect valid ends (e.g., energy conservation through solar legislation) of a state government [57]. 


\subsubsection{Limitations on State Authority}

A state cannot exercise its authority in areas preempted by the exercise of federal enumerated powers or in any way that thwarts the effectiveness of valid federal regulations [58]. Solar energy has characteristics that make it subject to federal regulation [59]. If the Federal Government acts pursuant to its enumerated powers and chooses to override state regulation, it can do so under the supremacy clause of the Constitution [60]. "[T] he government of the Union, though limited in its powers, is supreme within its sphere of action" [61]. So far, the Federal Government has chosen not to preempt much state legislation favoring the solar energy industry. Concurrent regulatory measures have been allowed, with the federal and state governments both passing legislation directed toward developing solar energy technologies [62].

States are constitutionally mandated not to pass laws which impair the obligations of contract [63]. There are a large number of contracts that could be made less profitable in the conventional energy industry and related industries, if an effective financial incentives program were enacted to aid the solar energy industry. Financial incentives could increase solar energy's share of the total energy market, causing the demand, prices, and profits of conventional energy sources to fall. Wholesale buyers of conventional forms of energy, who have entered long-term supply contracts with set prices and quantities for goods delivered, are one group that could be affected by the price reduction. If this were the type of situation contemplated by the Constitution, however, "all governmental action affecting the profitability of private concerns would violate the contracts clause because it would change relative values and make those enterprises, the prospects of which were diminshed by the legislation, somewhat less likely to keep their bargains" [64]. Obviously, the courts have not chosen to read the contracts clause limitation so broadly. The interpretation adopted by the courts is to read the clause as forbidding governmental rearrangement of the rights and responsibilities of two parties to an existing contract [65]. The "diminshed profitability and therefore diminshed ability to keep up obligations" [66] argument is not within the scope of the contract clause prohibition, and therefore, the contract clause should not be a real barrier to solar incentives legislation.

Another group that might argue state violation of the contracts clause is public utility companies who have acquired franchises, binding contracts from the state in which they are operating [67]. The existence of a franchise agreement does not preclude state regulations that confer benefits on a competing energy industry, unless the franchise contains express provisions that competitive energy facilities will not be allowed to operate [68]. Most jurisdictions do not allow such exclusive franchises. Those that do, however, will probably not be altering the obligations of the franchise by providing financial incentives favoring the solar energy industry. This is because provisions protecting against competition in the same services will probably not be violated by encouraging solar energy technologies [69]. For example, a franchise protecting a gas energy public utility from competition in gas energy will probably not preclude solar energy service because a gas energy public utility and a solar energy public utility are not the same service [70]. This argument will probably be successful unless the franchise prevents all energy suppliers from competing with the public utility. When possible, the courts will avoid this interpretation of the provisions in a franchise [71].

It should also be kept in mind that legislation which conflicts with the constitution is not valid. The contracts clause "must be construed in harmony with the policy power" and the taxing power of the states [72]. The contracts clause may have to be balanced against the police power and taxing power if they conflict. State actions that benefit the 
well-being of a state and result in incidental government alterations of the rights and obligations of certain contracts, may be allowed by the Constitution [73]. As a result, state action that benefits the solar industry may be allowed even when the franchise given to a public utility excludes competition from other energy suppliers, so long as the benefits from employing solar energy facilities outweigh the detriments of altering a provision of the franchise.

The best way to avoid challenges by public utilities to state regulation benefiting the solar energy industry is to keep such potential problem areas in mind when constructing or renewing franchise agreements. One should also seek to disclaim any intent to create an exclusive franchise which prevents widespread use of solar energy technologies.

Through the Fourteenth Amendment, most of the limitations on federal authority found in the Bill of Rights have been extended to the states [74]. State authority is also limited by restrictions found in the constitutions of the various states [75]. Solar policy makers in each state should be aware of the possibility of these restrictions and attempt to identify and avoid them.

\subsubsection{Sources of Local Authority}

A local government can exercise only those powers delegated to it by the state [76]. The delegation must be express [77], clearly made [78], or implied from the necessity of carrying out governmental policies [79]. The delegation may be made by constitutional provisions [80], statute [81], or charter [82]. Both the police power [83] and the taxing power [84] of the state can be delegated to local governments. Of ten the delegation will convey to the local governments some discretion in carrying out the authority [85]. Local governments are agents of the state and act on behalf of the state. This means that local governments can potentially wield most of the powers reserved to the state, thereby benefiting the solar energy industry.

\subsubsection{Limitations on Local Authority}

Since most local government authority is derived from the state legislature, the local government cannot exercise powers delegated to it by the legislature when the legislature itself does not possess the authority [86]. Therefore, local governments are limited by the same restrictions that state governments face, including the federal and state constitutions [87]. Local governments are also restricted by the boundaries of the grant of power itself and must exercise the delegated authority in strict conformity with the grant [88]. Local incentives for solar commericalization may therefore be suspect as being beyond the powers granted to the local government by the state.

\subsubsection{Summary}

The powers available to the three levels of government permit financial incentives favoring the development of solar energy technologies. Each level of government retains some form of the taxing power and a grant of authority to pursue socially desirable public objectives. Utilization of solar energy can be interpreted as being in the realm of public purposes. The major limitations to employing financial incentives can be eliminated by preventive legislation, careful construction of laws and regulations, and selection of incentives that are not overly burdensome on the private market. 


\subsection{TAX INCENTIVES}

Tax incentives are ordinarily an exercise of the taxing power, although if the regulatory aspects of the tax incentive are extensive, the commerce power or the police power may be relied upon by the enacting level of government.

\subsubsection{Income Tax Deductions}

Income tax deductions may be enacted on the federal level and in states that have income taxes [89], allowing a taxpayer to deduct a statutorily specified percentage of the cost of a solar energy facility from his adjusted gross income in the year that the facility was purchased [90]. The impact of this incentive will depend on the income of the individual or business acquiring the solar energy equipment [91]. Taxpayers in higher income brackets will usually be the only individuals to accrue tax savings [92]

There are a number of ways that tax deductions could stimulate the solar energy industry. The federal or state governments could permit an annual income tax deduction for a fixed percentage of the mortgage costs for a solar energy facility [93]; allow an income tax deduction on a fixed percent of the initial costs for a solar energy facility [94]; or permit corporations producing solar energy facilities to deduct items such as operating expenses, overhead, depreciation, and research and development expenditures from corporate income taxes [95]. Income tax deductions will result in increased sales of solar energy facilities by decreasing the costs of the facilities to consumers, or decreasing the costs of building the facilities to producers [96].

One of the greatest advantages of using tax deductions as an incentive is that the administration costs are relatively low. Administration of the tax deduction would be through existing institutions: the Internal Revenue Service or corresponding state agency [97].

Extending income tax deductions to consumers and producers of solar energy facilities should not present any major legal impediments. Similar incentives have been extended to encourage development of other energy technologies [98]. The existence of incentives to other industries does not preclude legal challenges to income tax deductions favoring the solar energy industry, but their presence indicates that under the proper circumstances, tax deductions will be allowed.

An American Bar Foundation study has identified a number of limitations to a program of tax deductions, which might significantly reduce its effectiveness in encouraging solar energy technologies [99]. A tax deduction: (1) normally is limited to business or income producing property, (2) can only be used by taxpayers who itemize their deductions, 3) will only be permitted in states that allow itemized deductions, and (4) will nnly henefit taxpayers with greater amounts of taxable income [100]. The study recommends that a program of income tax deductions not be adopted.

A number of bills allowing income tax deductions have been introduced [101] or enacted [102] on the state or federal level. The problem of favoring middle and high income groups is the major barrier to this form of financial incentive [103]. 


\subsubsection{Income Tax Credits}

Income tax credits can also be used on the federal level and in those states that have income taxes. This incentive allows a taxpayer to reduce his actual tax liability by a specified percentage of the cost of a solar energy facility, up to a maximum amount [104]. Income tax credits could also be extended to corporate income taxes [105]. Unlike the tax deduction, the amount of the tax credit does not depend on the income level of the taxpayer [106]. Nevertheless, for practical purposes, middle and upper income groups will probably be the only taxpayers with sufficient tax liabilities to take full advantage of the tax credit [107].

There are a number of ways that a tax credit could be fashioned to stimulate the development of solar energy technologies. For example, the Federal Government or a state government could allow a taxpayer to reduce his annual tax liability by a fixed percentage of the mortgage costs of a solar energy facility [108], or an income tax credit could reduce tax liability by a fixed percentage of initial costs [109].

The effectiveness of tax credits can be increased by three methods. First, the percentage and maximum amounts permitted for the income tax credit could be increased [110]. Second, if all of the tax credits cannot be used to decrease tax liability in one year, the remaining credit can be applied to future income tax liability [111]. Third, if all of the tax credit cannot be used to decrease tax liability in one year, the taxpayer may receive the difference in the form of payment from the government [112]. It should be noted that the second and third options would allow lower income groups to realize the full impact of a tax credit, assuming that with the second option, all lower income taxpayers will have sufficient tax liability over their lifetimes to use up the tax credit allowance.

As with the tax deduction incentive, adoption of an income tax credit should result in increased sales of solar energy facilities by decreasing the costs of the facilities to consumers [113].

In the business sector, the income tax credit is called an investment tax credit. Investment tax credits could be used to stimulate use of solar energy in the business sector by allowing tax credit for either a percentage of the initial cost or a percentage of the annual mortgage costs of a solar energy facility [114]. This incentive should increase sales of solar energy facilities to commercial consumers by decreasing the costs of the facilities [115]. Investment tax credits could also be extended to manufacturers of solar energy facilities [116]. A credit could be permitted on research and development [117], or on depreciable equipment and machinery [118]. This incentive should reduce manufacturing costs and cause the price of solar facilities to fall [119]. Income tax credits would also be administered through the Internal Revenue Service and would require an amendment to the Internal Revenue Code [120]. The existing administrative mechanism would lower the cost of the incentive to the government.

Existing laws allow income tax credits for some commercial equipment but not for building investments or active energy generating equipment found in a building [121]. A company that installs a solar energy facility in a building owned by someone else and then sells the energy produced to the owners of the building, may be eligible for a tax credit under existing laws [122]. Income tax credits have been used in the past as incentives for the development of other sources of energy [123]. This precedent provides a basis to defend the legal viability of extending similar incentives to solar energy. 
The number of income tax credit proposals and enactments has far exceeded those for income tax deductions, probably because the credits benefit more taxpayers. A number of studies indicate that the low cost and market penetration ability of income tax credits make them potentially effective incentives [124]. A number of states are considering or have passed legislation permitting income tax credits [125]. Provisions for tax credits have been included in the Energy Tax Act of 1978 (ETA), one of a series of acts which together have been referred to as the National Energy Act [126]. The ETA of 1978 provides a residential energy credit against one's personal income taxes for renewable energy source expenditures, provided that the expenditures are related to the taxpayer's principal residence, and that residence is located within the United States. These expenditures include material and labor costs properly allocable to the on-site preparation, assembly or installation of solar energy equipment.

The incentive structure allows for a $30 \%$ income tax credit for the first $\$ 2,000$ spent for solar equipment, a $20 \%$ income tax credit for the next $\$ 8,000$ spent, for a maximum credit of $\$ 2,200$ towards systems that cost $\$ 10,000$ or more.

There are certain limits to the residential tax credit, the most important of which is that the credit is not refundable in the current year, but may be carried over to the succeeding taxable year. There may be no carryovers after 31 December 87, and this incentive will be phased out completely by 1985. Also, the credit does not apply to swimming pools or greenhouses used as energy storage mediums which have primary functions other than the function of storage and heating.

"Renewable Energy Sources," that qualify for the residential income tax credit, are defined as property, which, when installed in connection with a dwelling, transmit or use: (1) solar energy, or any other form of renewable energy which the Secretary of Treasury specifies by regulations, and (2) wind energy for nonbusiness residential purposes. These properties must be reasonably expected to remain in operation for at least five years. Members of condominiums are allowed to deduct a pro-rata share of solar expenditures made for the benefit of the entire complex [127].

The ETA provides for additional investment credits to encourage consideration of, or conversion from conventional energy sources, and to encourage new solar energy technology. The energy percentage is equal to $10 \%$ of the cost of solar energy property, and is in addition to the regular $10 \%$ investment credit available for qualifying capital expenditures. Energy property is defined to include alternative energy property, solar or wind energy property, specially defined energy property, and recycling equipment. Alternative energy property which qualifies includes equipment for converting alternative substances into synthetic liquids or fuels (biomass). To qualify for the investment credit, the energy property must have a useful life of three years or more. Public utility-owned property is specifically excluded for the purposes of this investment credit. Solar or wind energy property includes any equipment that uses solar or wind energy to generate electricity or to heat or cool (or provide hot water for) a structure. Any qualifying solar property that has been financed by tax-free development bonds may only take a $5 \%$ investment credit rather than the full $10 \%$ credit.

Contrary to the residential energy credit, which is not refundable, the investment credit for solar or wind energy property is refundable.

A considerable caveat to the solar energy investment credit is that the definition of solar equipment does not include passive solar equipment. Only active solar equipment qualifies for the $10 \%$ investment credit [128]. 


\subsubsection{Accelerated Depreciation Allowances}

The value of depreciation a taxpayer is permitted to take directly affects his income tax liability in a given year. This incentive is primarily used by corporations, utilities, people in high tax brackets who install solar energy facilities, and manufacturers who produce the facilities [129]. These groups would be allowed either to depreciate the capital invested in solar equipment or to use a more liberal method of tax deduction for depreciation than at present.

Depreciation incentives can be instituted in a number of ways. For example, a homeowner could be permitted to depreciate the capital he has invested in solar equipment over a set period of time [130]. A corporation or utility could be allowed to compute depreciation over a shorter period of time than now permitted, or use methods of depreciation that allow deduction of capital costs in greater amounts at the beginning of the amortization period [131]. Another method would be to allow accelerated depreciation on equipment used to manufacture solar energy equipment [132]. The first two methods would benefit the development of solar technologies by decreasing the costs of the solar energy unit and increasing cash flows by the amount of the excess depreciation exempt from taxation [133].

Accelerated depreciation, as an income tax incentive, would be administered by the Internal Revenue Service and require an amendment to the Internal Revenue Code [134]. The costs of administration would be low because it would not require any major changes in existing tax systems.

As with income tax credits and deductions, there do not seem to be any major legal impediments to allowing accelerated depreciation deductions from income taxes. In fact, an argument can be made that not allowing homeowners the ability to depreciate their solar energy facilities violates the equal protection clause of the Fourteenth and Fif th Amendments. Institutional owners of conventional forms of energy are allowed to depreciate their equipment, but homeowners are not [135]. Homeowners could argue that during the present energy crisis, the depreciation allowance to institutional owners is a classification which is not reasonably related to a proper governmental objective [136]. The governmental classification encourages the use of inherently scarce resources and as a result discourages use of the sun, a potentially limitless source of energy. This argument would probably not be successful because of the amount of discretion given to legislative bodies by the courts [137].

Certified pollution control facilities are allowed rapid amortization periods [138]. Owners of pollution control facilities can amortize the first 15 years of the normal life of the facility in the first 60 months of operation [139]. Accelerated depreciation has also been used in the past to promote the expansion of beneficial industries like warrelated plants [140]. Many of the reasons used to justify accelerated depreciation for these facilities are analogous to the reasons for encouraging the use of solar energy. These analogies may be helpful in a court challenge against allowing accelerated depreciation for solar energy installations.

Some states have considered or passed legislation to allow rapid amortization of solar energy facilities [141]. The Federal Government is considering but has not passed legislation using this incentive [142].

Accelerated depreciation allowances could be an effective incentive for developing solar energy technologies. The major problem with this incentive is its inability to confer 
direct tax benefits on all levels and types of income groups that might use solar energy facilities. Probably the most equitable way to use this incentive would be to allow producers of solar energy facilities the option of using accelerated depreciation on the capital equipment employed to manufacture the facilities. This would lower the operating costs of producing solar energy facilities, making the transition to solar energy more cost-effective to all taxpayers.

\subsubsection{Tax-Exempt Bonds}

Issuance of tax-exempt bonds is a means to acquire low-cost funding of solar energy facilities for private and public parties [143]. The most promising uses of this type of funding will probably be found on the municipal level of government [144]. Because some forms of state and municipal bonds are being exempted from federal income tax, the bonds can be sold at a much lower interest rate [145]. The exemption functions as a federal subsidy to local financing efforts.

Whether a specific issue of bonds is eligible for tax-exempt status will usually depend on the form of bond being used and the nature of the activity being financed by the proceeds of the bond issue [146]. The three major types of bonds, all potentially applicable to financing solar energy facilities, are general obligation bonds, revenue bonds, and improvement or assessment bonds [147]. Since the analysis for general obligation bonds is more germane to government grants, they appear under that heading.

Revenue bonds are promises of the issuing municipality to pay the principal and interest amounts set in the bond, with the revenue obtained from the facility built with the proceeds of the bonds [148]. Where revenue will be obtained from rentals under a lease, the issuing authority must be able to lease the property and use the lease proceeds from the rentals to meet the bond obligations [149]. Where revenues will be obtained from tools, rates, or charges on use of the property financed with the proceeds of revenue bonds, the issuing authority must have the authority to obtain those revenues [150]. Additional security may be obtained if statutes authorize the issuing authority to mortgage the facility [151].

If proper legislative provisions are enacted, revenue bonds could be used to provide lowcost financing of industrial and residential solar energy facilities. One form of revenue bond that could be used to finance solar energy facilities for private business is called an industrial development bond [152]. The Internal Revenue Code describes an industrial revenue bond as a bond where the proceeds are paid to a private business in return for its promise to repay [153]. In the past, industrial development bonds were used by municipalities to encourage expansion of private industry. The Federal Government restricts the use of this low-cost financing mechanism to benefit private industry, and only a small number of specific projects are allowed tax-exempt status under industrial revenue bonds [154].

The Internal Revenue Code provides tax-exempt status to bonds used to finance facilities for local furnishing of electric energy or gas [155]. This provision is potentially applicable to some solar energy facilities. Air and water pollution control facilities are another class of projects where bond financing is exempt from federal taxation [156]. Pollution control is one of the many public advantages of converting to solar energy. Solar energy facilities are not expressly included in the list of tax-exempt projects, but the Internal Revenue Code could be amended to include them. 
Without a revision in the Internal Revenue Code to allow tax-exempt status for bond financing of solar energy facilities, an argument can still be made that by the doctrine of intergovernmental tax immunities [157] the Federal Government may not tax interest on municipal bonds. The thrust of this doctrine is that the federal and state governments are not allowed to tax each other's activities. One old Supreme Court opinion considered a situation much like the one presented, in which the court upheld the federal tax exemption on an issue of municipal bonds [158]. If this holding is sound precedent today, it could be used to invalidate the federal government restrictions on income tax exemptions for industrial development bonds. Even though the case has not been expressly overruled, the recent trend to reduce the scope of the intergovernmental tax immunities doctrine might cause the Supreme Court to reach different conclusions today [159].

In a study for the city of Santa Clara, California, Sharon White has developed some possible uses for other forms of revenue bonds [160]. Proceeds from an issue of revenue bonds could be used to purchase, install, and maintain publicly owned solar energy equipment in private homes or businesses. Revenue to make payments on the bond obligations could be obtained by imposing use charges on the equipment. Proceeds from an issue of revenue bonds could be used to finance construction of a central solar public utility. The municipality could charge a fee for use of the solar-heated water or solarproduced electricity to make the necessary bond payments. This example would parallel the traditional use of revenue bonds to finance local public utilities.

Assessment bonds are promises of the issuing municipality to pay the principal and interest amounts set in the bond, using the funds obtained through assessments levied on property that receive especial benefits from the construction or improvements that are being financed by the bonds [161]. This requires that the issuing entity have the constitutional, statutory, or charter authority to assess the benefited property for the particular construction or improvements made [162]. Laws will have to be changed in jurisdictions that do not have the authority to assess benefited property for installation of solar energy facilities [163].

Assessment financing requires that the improvement confer both a general benefit on the public at large [164], and an especial and local benefit upon the property that is to be assessed [165]. Although some jurisdictions have subjective criteria to determine what constitutes an especial benefit [166], the majority of jurisdictions define especial benefits in terms of the increased value of the assessed property [167]. This distinction may become important when a court attempts to determine the validity of an assessment by balancing the costs and benefits of the facility that will give rise to the assessment [168]. Subjective criteria could result in underevaluation of the benefits of solar energy by those who might favor other energy technologies. The underevaluation could eliminate the net benefits required for the assessment financing. Universal adoption of the majority view of calculating especial benefits could reduce the effects of this bias.

There are a variety of ways that assessment bonds could be used for low-cost financing of solar energy facilities. The proceeds from an issue of assessment bonds could be used to purchase and install solar energy equipment in private homes or commercial buildings in localized areas. Bond proceeds could also be used to build a central solar energy plant that supplies energy to some of the buildings in a community. In the past, courts have allowed issuance of assessment bonds to fund conventional energy-producing plants as long as the energy that was produced in a single plant supplied only a portion of the energy needs of a community [169]. 
Sharon White argues that case law supports the conclusion that assessment financing of solar energy facilities will not be invalidated because the property being assessed is already serviced by a nonsolar energy facility [170]. Her conclusion is derived from analogous cases that uphold assessment financing to replace overhead electrical facilities with underground facilities, and by other cases "which generally support the installation of local facilities as a modernization of the method theretofore employed by the property owner" [171].

Tax-exempt bonds are a potential means to provide low-cost funds for construction and installation of solar energy facilities. Legislation should be enacted to ensure that solar energy facilities are eligible for bond financing and federal tax exemptions on the interest accumulated by the bondholder. Traditional use of bonds to finance local public utilities would make it an ideal source of funds for some types of solar energy equipment. The low financing costs will be geared toward reducing the costs of solar energy facilities to consumers and producers, resulting in increased sales of the facilities.

\subsubsection{Property Taxes}

All states [172] are currently buying property taxes on residential and commercial property [173]. These taxes are assessed on property or a class of property in a given area [174], and for the most part are being collected at the local level [175].

Property taxes could be used to advance the use of solar energy technologies if purchasers of solar energy facilities could be exempted from paying part or all of the property taxes on the increased value of the property due to the facility improvement. The incentive would increase sales of solar energy equipment by decreasing the costs of the equipment to the consumer. 'The cost savings could be significant, because property taxes can contribute as much as $25 \%$ to the cost of solar energy facilities [176]. Property tax incentives could also be used to encourage solar easements [177]. For example, the owner of a solar energy facility could be exempted from paying taxes on the increase in the value of his land due to the recognition of a solar easement over his neighbor's property [178].

Administration costs should be quite low because the property tax incentive could be carried out by local departments of revenue already in existence. In most cases, state and local revenue codes or delegating legislation would have to be amended to allow for property tax exemptions.

The Federal Government is precluded from levying property taxes by constitutional mandate [179]. It has been suggested that the Federal Government could ensure property tax exemptions on the state and local level by compensating the state or locality for the lost tax revenue due to the exemption [180]; by allowing federal income tax credits to compensate the individual owner of a solar energy facility for any increase in property taxes due to the facility [181]; or by withholding federal subsidies if a state or locality fails to enact appropriate property tax exemptions [182]. This sort of action by the Federal Government could be subject to challenge on constitutional grounds. A court could determine that such federal interaction is sufficient interference with state actions to constitute a usurpation of sovereign powers reserved to state governments [183], or that the Federal Government is trying to indirectly exercise powers that it is forbidden to use directly [184]. If either of these situations are found in court, the federal actions may be terminated. Federal reimbursement or tax credit plans could also be subject to abuse by tax assessors, assessing solar energy facilities at excessive rates, knowing the Federal Government would absorb the loss to the taxpayer [185]. 
Whether a solar energy facility is even subject to property taxation may depend on how a solar facility fits the statutory definition of property in each state [186]. Statutory definitions of property subject to taxation usually include words like "structures," "fixtures," and "improvements." Some states even tax personal property [187]. Solar energy facilities could conceivably fit any one of these categories. If a solar energy facility were classified as personal property in a state that levied property taxes only on real property, the facility would be exempt from taxation.

The way property is valued when it is subject to taxation may be an important consideration when fashioning tax-exempting legislation. The valuing systems include market value, which is often used for private residences; the value of income generated, which is of ten used for commercial property; and present replacement cost [188]. Legislation that exempts solar energy equipment from property taxation where property is assessed according to income generated, will not be effective [189].

The Federal Constitution allows states to establish different tax classifications as long as the classifications are reasonable [190]. State and local authorities, however, are also limited by their own state constitutions, statutes, and charters [191]. Reasonable classifications incorporated in state laws will generally be upheld under equal protection challenges [192]. State laws having uniformity clauses which require that similarly situated property or similar classes of people be taxed at the same rates, may create a problem in some states [193]. The Supreme Court has indicated that it will not overturn reasonable classifications in property taxation, despite the existence of uniformity clauses, as long as the state has a settled practice of class differentiation [194]. Many state courts have chosen not to accept this invitation and have required uniformity in property taxation when state constitutions or statutes specify it [195]. To avoid this dilemma, it is recommended that policy makers repeal any laws that require uniformity in taxation [196]. The Fourteenth Amendment will present abuses in tax classifications.

Fallout shelters, pollution control facilities, nuclear power plants, union halls, and homesteads for disabled veterans are among the items that have received property tax exemptions [197]. Some form of property tax exemption for solar energy facilities has been enacted in at least 30 states, making it a widely used financial incentive [198]. A National Science Foundation estimates that property tax exemptions could increase the predicted use of solar heating and cooling by $38.6 \%$ in the year 2000 [199].

Property tax exemptions are being used effectively in some states and should be encouraged in others to promote the rapid development of solar energy technologies. The legal impediments are far from insurmountable and can usually be eliminated. Since property tax structures are regressive, exemptions for solar energy facilities would benefit all income classes equally. The low administration costs of utilizing property tax incentives increases their effectiveness.

\subsubsection{Sales and Use Taxes}

A sales tax is a tax levied by a state or local government on the purchase, sale, or gross receipts from sale, on a wide range of commodities [200]. A use tax is a tax imposed upon property purchased outside the state or otherwise not subject to a sales tax [201]. The use tax is complementary to the sales tax and is used to equalize the tax burden on in-state and out-of-state merchants [202]. This close relationship between the two taxes has of ten resulted in similar treatment in legal analysis. 
State constitutions, statutes, and charters usually define who and what are subject to sales and use taxes [203]. Policy makers must examine their own sources of authority to determine which transaction along the manufacturing, distribution, transportation, storage, and sales process will subject a solar facility to sales or use taxes. This incentive is directed toward relief from sales or use taxes at any one or more transactions. The relief would act to increase sales of solar energy facilities by reducing the initial cost to the purchaser.

Like other tax incentives, administration costs will probably be low because the incentive will be carried out by existing tax agencies. Specific exemptions would have to be made to existing state tax laws for those transactions, from production to final sale, that are to receive the benefits of the incentive.

As with property taxes, the Federal Government is not allowed to levy sales or use taxes [204]. Federal compensation to state and local governments for lost revenue due to the exemption, to private individuals for increases in sales and use taxes, or federal withholding of subsidies to state and local governments for failure to enact sales and use tax exemptions, may be subject to constitutional challenge. Federal participation may be seen as encroachment on sovereign powers reserved to state governments [205].

Whether solar energy facilities are subject to sales or use taxation may depend on the definitions of sales and uses subject to taxation in each jurisdiction and how each particular facility is utilized. A solar energy system, installed during the construction of a private residence, may be considered building material, a fixture, or supplies which may be bought and used by a contractor without a taxable sale being made [206]. Some jur isdictions exempt public utilities from sales and use taxes, which may include the raw materials used in providing energy sources [207]. These statutes may already forgive sales and use taxes for central solar energy power plants. Some jurisdictions expressly include retail sales of energy in sales tax statutes [208], and will require special sales and use tax exemptions for solar energy facilities.

Uniformity clauses in state constitutions and tax statutes may also be applicable to sales and use taxes. Many courts have held state uniformity clauses applicable only to property taxes [209]. However, express provisions in uniformity clauses that require unif ormity in nonproperty taxes, excises, or use and sales taxes may forbid exemption of solar energy facilities from sales and use taxes [210]. The best way to avoid potential uniformity clause limitations is to eliminate state uniformity clauses and rely on Fourteenth Amendment equal protection rights to guard against abuses in tax rlassifications.

Sales or use tax exemptions have been enacted in only a few states [211]. Among the items that have been exempted from sales taxes and use taxes in the past are sales of energy by public utilities [212], sales of motor vehicles [213], and sales of agricultural products [214]. The effect of sales and use tax exemptions may depend on the amount of the exemption, as well as the tax rate in a jurisdiction, and tax rates vary significantly among the various states [215]. Overall, studies indicate that sales and use tax incentives would not have as much impact on the development of solar energy technologies as some of the other tax incentives [216].

Removing sales and use taxes from the purchase price of solar energy facilities would reduce their initial costs. Sales and use tax exemptions should be combined with other monetary incentives to be an effective commercialization device for the solar energy industry. Any legal obstacles could probably be eliminated by preventive legislation. 
The two greatest advantages of this incentive are the low costs of administration and the equitable treatment of all income classes.

\subsubsection{Summary}

Tax incentives have found the most popularity in existing legislation. They are capable of being administered under present institutional agencies. Policy makers are familiar with these institutional mechanisms and can manipulate them at comparatively low costs. By isolating the problem areas, legislators should be able to modify existing laws to eliminate any potential legal impediments to tax incentives.

\subsection{LOAN INCENTIVES}

Governmental involvement in loan incentives generally involves exercise of the federal commerce or spending powers, or exercise of the state police or taxing powers,

\subsubsection{Low Interest Loans}

Low interest loans, applicable to both residential and commercial projects, could be provided by all levels of government. This incentive would decrease the long-term costs of financing capital-intensive solar energy equipment [21.7].

A low interest loan incentive program could be implemented through existing institutions or new agencies [218]. The loans could be provided directly by the government, or the government could subsidize loans given by private lending institutions to private borrowers [219].

Low interest loans could be extended by the Federal Government to commercial enterprises interested in purchasing solar energy equipment through the Small Business Administration (SBA) [220]. The SBA could be authorized to loan low interest funds directly to qualifying businesses, or to subsidize the same loan through a private financial institution by paying either the private institution or the borrower the difference between the market interest rate and the interest rate set for the incentive [221].

Another proposed method would permit private lenders to accept loans on homes containing solar energy facilities at a subsidized interest rate. The Government National Mortgage Association (GNMA) would purchase the loan from the private lender at the subsidized rate of interest and either retain the mortgage itself, or resell it to the other principal secondary market entitites; the Federal Home Loan Mortgage Corporation (FHLMC) or the Federal National Mortgage Association (FNMA) [222]. This program is structured after an existing program providing low income housing, commonly referred to as the FNMA/GNMA Tandem Plan [223]. The major advantages to this program would be that existing agencies would be used to administer the loan, resulting in low administrative costs, and the borrower would be doing business with the private institutions, avoiding excessive governmental involvement.

Assuming that the Federal Government decides to exempt interest payments on state and local revenue bonds from federal income taxation, as discussed earlier, those funds could be used for low interest financing of solar energy facilities. 
These examples are only a few of the possible programs that could be used to extend low interest loans to encourage the development of solar energy technologies. Most of the methods presented could be implemented by existing government agencies that are familiar to policy makers and would require low administrative costs.

Low interest loan programs are usually equitable. Lower income groups traditionally pay higher interest rates for borrowed money, but because of their lower tax brackets, do not receive as much savings from interest deductions [224]. The incentive can also be fashioned to provide low cost loans to private and commercial solar energy facilities [225].

Potential legal impediments to providing low interest loans seem to be limited to the issues developed in the preliminary considerations. Low interest loans have been used in the past as incentives to encourage a variety of social welfare objectives. Low interest loans have been used to provide educational opportunities to students in institutions of higher learning [226], and to provide housing for low income families [227]. An existing program which could have applications for solar energy technologies is a project administered by the United States Department of Agriculture [228]. The Farmers Home Administration provides low interest loans to low and moderate income families that live in rural areas for certain conservation measures, which could be applicable to some types of passive solar energy systems [229]. Because structural work is not allowed, the program excludes active solar energy facilities [230]. The National Energy Conservation Policy Act of 1978 includes two provisions, that allow the GNMA to purchase low interest loans for both active and passive solar energy systems [231]. One provision sets up a $\$ 100$ million, five-year revolving fund for the GNMA to purchase loans for both active and passive solar energy systems. All families are eligible borrowers for loans not exceeding $\$ 8,000$. The interest rate would be set between $7 \%$ and $12 \%$. Any tax credit taken for the same system must be reduced by the amount of the interest subsidy [232]. The second provision sets up a $\$ 3$ billion revolving fund for GNMA to purchase home improvement loans for energy conserving measures. Elderly and moderate income families are to receive priority for the loans, which are not to exceed $\$ 2,500$ [23.3] .

A government program of low interest loans to finance purchases of snlar energy facilities will probably not meet any major legal obstacles. Administration costs could be kept low if existing federal and private means for providing housing loans and the SBA are used to implement the program [234]. The equitable effects of low interest loans also make them desirable incentives. It should be noted that government borrowing for this purpose will probably not be great enough to significantly distort the sapital market [235]. Bezdek points out that the low interest loan programs have the potential of generating public support [236].

\subsubsection{Government Guaranteed Loans And Insured Loans}

The purpose of a loan guarantee or an insured loan program is to place the full faith and credit of a governmental entity behind the borrower [237]. This means that the creditor can look to the government guarantor for the balance of the loan payments if the borrower defaults on the loan. Under an insured loan program, the government collects a premium from borrowers when the loan is taken to provide funds to cover lenders for defaul ts [238].

Government guaranteed loans and insured loans could be administered through existing agencies which already have some form of guarantee or insurance program for loans, 
existing agencies that could be easily modified for such a program, or new agencies [239]. Either type of loan program could be extended to residential or industrial purchasers of solar energy facilities [240].

Government guaranteed loans and insured loans are geared toward reducing lender uncertainty by increasing the number of loans that can be made to purchasers of solar energy facilities without excessive danger of default [241]. This may lower interest rates slightly, and more importantly, may avoid further increases in the interest rates charged to finance solar energy facilities [242]. Another advantage from the reduced risks would be that lenders will be more willing to finance a larger amount of the solar energy facility, which will lower the down payment (the initial cost) required from a borrower [243].

Administration costs could be kept at a minimum if existing agencies were used to implement guaranteed or insured loan programs [244]. The costs of the entire loan guarantee program would depend on the default rate. If the default rate is low, as some studies predict, the costs of such a program would probably be lower than most other financial incentives [245]. The costs of an insured loan program would be even less than the costs of a guaranteed loan program, because premiums collected from borrowers would cover all or part of the costs of default.

Although a guaranteed loan or insured loan program could be developed on any level of government, the Federal Government is most suited to offer this incentive. The government entity would guarantee or insure all or part of a loan made through a private lender to finance the costs of a solar energy facility. Often, ceilings are placed on the amount of a loan that is eligible for loan gaurantees or insurance. For solar loans, ceilings should be set very high and differentiated for the various types of solar energy technologies. For example, loan ceiling set for homeowners to purchase active solar water heating systems would be much too low for funding a central solar energy power plant.

A government organization that would be an ideal adminstrator for a guaranteed or insured loan program for residential buildings would be the Federal Housing Administration (FHA). At present, the FHA has an insurance fund for providing home loañs to moderate income groups and loans for apartments, cooperatives, nursing homes, and group medical practices [246]. FHA loans have been used to provide funding for solar energy facilities [247]. The FHA could establish a firm policy of insuring loans to finance solar energy facilities.

The program currently being implemented by the Rural Electrification Administration (REA), could also extend guaranteed loans to finance the construction of electric generating facilities under cooperative ownership [248]. This program could finance the construction of centrally located solar energy plants producing electricity, or could be modified to allow for all solar energy utility plants.

The SBA has the authority to guarantee loans for small businesses meeting their qualifications [249]. Although some solar energy companies would qualify for these loans, many would not, for such reasons as lack of sufficient collateral or the excessive risk of a new operation. More solar energy companies would qualify for the guaranteed loans if the SBA were allowed to guarantee all or a higher percentage of the private loans, a program under consideration by Congress [250]. The U.S. Department of Energy is opposed to this move because it feels small business loans should be based on sound financial practices with similar requirements for all businesses [25l]. 'The SBA guaran- 
teed loan program could easily be changed to allow for insured loans. All that would be required is for the SBA to collect a premium for estimated defaults and pay for defaults out of that fund.

Other variations could use existing governmental organizations or create new organizations. Most of these proposals would require amendments to federal statutes and appropriate regulatory provisions.

Guaranteed loans and insured loans will benefit all income groups in the residential and commercial sectors. Assuming low income groups are able to make loan and insurance premium payments, they may receive the greatest benefits, since low income groups have the most trouble securing loans [252].

No major legal impediments appear to exist for governmental support of guaranteed loan or insured loan programss to encourage the develnpment of solar energy teohnologico. There are a number of applicable government programs that benefit the solar energy industry and have not met any significant legal challenges. The Energy Conservation and Production Act extends loan guarantees to finance qualifying solar energy facilities [253]. The Housing Act of 1968 allows the Department of Housing and Urban Development to guarantee loans to finance a number of community projects, including some solar energy facilities [254]. The FHA has insured some loans that were used to finance solar energy equipment [255]. The National Energy Conservation Policy Act amends the National Housing Act to include home improvement insurance for additions, alterations, or improvements that utilize both active and passive solar energy to reduce the conventional energy requirements of that structure [256]. The National Housing Act is also amended to make federal loan insurance available for active and passive solar energy improvements for multifamily housing projects. Under this provision, $90 \%$ of the losses to the holder of the loan will be insured by the Federal Government. Premium rates have not yet been set [257].

Administration and program costs could be quite low if existing government agencies are used and defaults are low. Federal funds would not even have to be expended unless a project fails. If lenders are confident that the government will compensate them for defauilts, capital will become available [258]. Depending on the amount of the loan payments, all income classes could benefit from this incentive. A program of guaranteed loans and insured loans would be more effective if they were used in conjunction with low interest. Inans.

\subsubsection{Secondary Market Constraints}

Secondary market entities purchase a vast number of the mortgage loans made in the primary loan market to maintain liquidity in the latter [259]. The two major serenniary markel entilies, the Federal Home Loan Mortgage Corporation (FHLMC) and the Federal National Mortgage Association (FNMA), have viewed this liquidity function as requiring a conservative position towards underwriting the risks of unproven technologies [260]. Even though no express policy on the treatment of solar energy technologies has been issued by FHLMC or FNMA, adminstrators in these organizations have indicated that their policy will probably exclude all or part of a solar energy facility from the value of the mortgage, and refuse high loan to value loans on projects whose energy needs are supplied by solar energy facilities [261]. This policy will probably continue as long as solar energy facilities are in the experimental stage [262]. Primary lending institutions may avoid making loans to some projects with solar energy facilities, because it would 
reduce their ability to sell those loans on the secondary market, diminishing their source of loanable funds.

FHLMC and FNMA are privately owned but heavily regulated by the Federal Government [263]. They "were established and continue to serve as instruments of federal housing policy. As such, they feel an obligation to be responsive to Presidential and Congressional appeals for their cooperation in advancing public objectives"' [264], which could include support of solar energy technologies. Congress and the executive branch should appeal to FHLMC and FNMA to make an exception to their traditional conservative policy, using their funds to purchase solar energy system loans. Such an appeal could benefit all income groups and would have neglible costs.

The National Energy Conservation Policy Act includes provisions that authorize GNMA, FHLMC, and FNMA to purchase loans for active and passive solar energy facilities. This may reduce some of the rigidity that the secondary market entities have expressed toward solar technologies [265].

Hopefully, governmental influence will be exercised in the secondary market to free loanable funds for solar energy facilities that are not available now.

\subsubsection{Statutory Constraints}

The Home Owners Loan Act of 1933 [266] is an important federal statute, which applies to federally chartered savings and loan associations, comprising about $60 \%$ of all the assets of savings and loans [267]. A savings and loan association covered by the Act can hold loans exceeding $\$ 60,000$, only up to an amount equaling $20 \%$ of the association's assets [268]. In some regions, this limitation precludes people from purchasing even average-priced solar energy facilities in buildings [269]. Homes, apartments, and businesses that desire these loans to purchase solar energy facilities are likely to exceed $\$ 60,000$ because of the high initial costs of solar energy systems [270].

A recent study prepared for the U.S. Department of Energy proposes three possible changes to this statute: (1) the Act could be amended to increase the $\$ 60,000$ limit, (2) the Act could be amended to require that only the amount exceeding the $\$ 60,000$ limit be computed in the amount that cannot exceed $20 \%$ of an association's assets, and (3) the Act could be amended to provide exemptions for buildings using solar energy facilities [271].

People with homes built under the Department of Housing and Urban Development's solar energy demonstration project are eligible for the under $\$ 60,000$ loans as long as the total costs of construction of the project minus the costs of the solar energy system do not exceed $\$ 60,000[272]$.

The Homeowners Loan Act also prevents applicable savings and loan associations from making loans without first having liens on real property [273]. Where the Act is not applicable, state banking charters generally include similar restrictions, which exclude many people from receiving these low interest loans if they desire to retrofit their homes with solar energy equipment [274]. Interest rates are important to purchasers of solar energy facilities because of the high initial costs.

One way to alleviate this problem with retrofits would be to exempt them from the first lien requirement; another way would be to refinance the whole property and include the 
solar energy facility in the new loan [275]. Factors such as changes in the rate of interest, the amount of the unpaid mortgage, and the cost of the solar energy facility will determine the desirability of the second alternative. Savings and loan institutions in some states permit open-ended mortgages that allow property owners to borrow back the original amount of the loan, after paying off a portion of it [276]. This may be a disadvantage to lenders in periods of rising interest rates. Wraparound mortgages may be another possibility. This method of financing allows a new loan to be tacked on to the existing mortgage. The interest rate is somewhat higher, but the entire mortgage could be considered a first lien for purposes of the Act [277].

\subsubsection{Summary}

Legislation to increase the availability of attractive loan financing for solar energy facilities have not been as popular as tax incentives. As a result, there are numerous ways that existing institutions and statutes could be modified to make funding more readily available to people desiring solar energy systems. The costs of loan incentive programs depend on the particular program being considered, but some types of loan incentives could provide the lowest cost program with the greatest stimulating effects on the solar energy industry. No significant legal impediments forbid the use of loan incentives.

\subsection{GOVERNMENT TRANSPER NCENTIVES}

\subsubsection{Federal Grants in Aid}

Cooperation between the federal and state governments and private organizations will probably be important in carrying out policies directed toward the commercialization of solar energy. The Federal Government of ten has funds and research facilities, but lacks the ability to effectively implement and enforce solar energy programs because of the size and diversity of the regulated industry. State and local governments and private organizations can effectively implement and enforce solar energy programs but lack necessary funds, research programs, or the impetus to do so because of the influence of countervailing economic forces, spillover effects, and unsettled questions of solar rights. Federal grants can compel state or local government or private implementation, and enf orcement of solar energy commercialization policies [278].

A grant is made when the Federal Government transfers money, property, services, or anything of value, to a state government, local government, or private recipient in order to accomplish an activity with a public purpose [279].

A grant is not a gift, but creates a contractual relationship between the federal grantor and the grantee [280]. All grants have stated obligations and restrictions agreed to by both parties, which become mutually enforceable provisions of the grant during the period that the grantee uses the funds [281].

It is impossible to summarize all of the ways that federal grant programs could subsidize the solar energy industry. Grants to owners of buildings for all or part of the cost of solar energy facilities would result in increased sales of solar energy facilities, by decreasing the initial costs [282]. Similar grants, extended to manufacturers of solar energy systems to purchase capital or decrease operating costs, would reduce initial costs of the systems [283]. 
Federal grants could be given to state and local governments to help fund their own tax, loan, or grant incentives programs.

The Federal Government could also use the leverage of the numerous other grants it extends to dependent states and localities. The State and Local Fiscal Assistance Act of 1972 , will provide $\$ 30.5$ billion dollars in revenue-sharing funds to state and local governments over a five-year period [284]. Even the so-called "no strings" approach to revenue sharing requires that certain conditions be followed by the grantee to retain the funds [285]. This type of grant incentive could be utilized by making some or all federal grants conditional on state or local governments, or private organizations enacting and implementing their own programs to encourage the commercialization of solar energy facilities.

Administrative costs of a federal grant program could be significant, depending on the extent of the program. A small grant program could be administered by existing institutions, but a large program would require a relatively large administrative mechanism to process the greater number of grant applications [286].

A grant program may tend to favor middle and upper income groups because lower income groups may not have the funds to initiate or complete the usually extensive application process [287].

One study claims that grant funds can be used most effectively when they are directed at specific projects [288]. More specific projects will require the Federal Government to place more conditions on how the grantee may use the grant. The recent case of National League of Cities v. Usury has identified some of the limitations on federal control over state policies and may be applicable to some grant programs [289]. The Usury case is an example of Congress exercising its "power so as to force directly upon the States its choices as to how essential decisions regarding the conduct of integral governmental functions are to be made" [290]. "[T] here are limits upon the power of Congress to override state sovereignty, even when exercising its otherwise plenary powers to tax or to regulate commerce which are conferred by Article I of the Constitution" [291]. The critical questions seem to be: (1) What is the extent of federal encroachment on the sovereign powers held exclusively by state governments resulting from a grant? and (2) What is the extent of federal interest in insuring that its funds are being spent on federally defined social welfare objectives [292] ? Probably the best way to avoid this challenge is to avoid excessive use of solar conditions on nonsolar energy system grants [293]. Justice Blackman, who concurred in the Usury case, characterized the decision as a "balancing approach" which "does not outlaw Federal power in areas such as environmental protection, where the Federal interest is demonstrably greater and where state facility compliance with imposed Federal standards would be essential" [294].

Another important consideration that should be kept in mind is that despite the enforceable obligations created in a grant, there is some uncertainty as to whether the Federal Government grantor can require the grantee to "specifically perform" his obligations under the grant, or whether only further funding can be terminated in the event of a breach in the terms of the grant [295]. This uncertainty might reduce the ability of the Federal Government to insure that all the funds it spends on grants to develop solar energy technologies will be used for that purpose.

There has been some use of federal grant incentives for encouraging the use of solar energy facilities. Probably the most popular of these programs has been the Department 
of Housing and Urban Development's solar equipment demonstration grants [296]. In June 1977 , over $\$ 6$ million was granted under this program [297].

The National Energy Conservation Policy Act contains a number of grant provisions. The Act authorizes weatherization grants, which include some passive technologies, to low income families. There are $\$ 530$ million authorized for the grant through fiscal year 1980 , with a maximum grant of $\$ 800$ for any dwelling unit [298]. Another weatherization grant program was established under the FHA for low income families in rural areas. Twenty-five million dollars have been appropriated for this program [299]. The Department of Housing and Urban Development has also been authorized to extend up to $\$ 25$ million in grants to help purchase active and passive solar energy system improvements for housing projects that were financed by loans made under section 202 of the National Housing Act [300]. Over the next three years, schools and hospitals will be eligible for grants aggregating up to $\$ 900$ million, to purchase and install active and passive solar energy facilities [301].

The greatest criticism of grant programs is the high cost of the exclusion of lower income classes from utilizing the incentive. Nevertheless, the general public seems to favor grant programs, and the promptness of receiving the proceeds of the grant make it a desirable incentive [302]. The only potential major legal impediment is vinlatinn of the doctrine of intergovernmental immunity, which can be avoided in most cases by careful construction of the grant.

\subsubsection{State and Local Grants in Aid}

A state grant in aid occurs when the state government transfers money, property, services, or anything of value, to a local government or private recipient. A local grant in aid is a transfer of money, property, services, or anything of value to a subordinate local government or private recipient. The ways grants can be used, the advantages and the disadvantages, are generally the same as in federal grants.

One difference is that states are not subject to the legal shallenge nf intergovernmontal immunities, as long as the state government does not encrnach on the governmental powers it has delegated to the local government.

A funding mechanism that is ideal for use on the local level to provide funds for grant purposes, is general obligation bonds. General obligation bonds require that the issuing entity pay the principal and interest that becomes due on the bonds [3ก.3]. The security for this requirement is a pledge of the full faith and credit of the issuing entity supported by its power to tax, raise, and collect sufficient funds to meet its obligations as specified in the bond [304]. Payments due on issued bonds can be made from any funds available to the municipality as long as taxes are levied to subsidize any shortage in funds being used for the payments [305]. Two direct limitations may arise on general obligation bonds used to finance solar energy facilities. Since local governments obtain most of their powers from delegation of state authority, some states have expressly limited the amount of bonds that can be issued by a municipality [306], or have expressly limited the amount of money that can be raised by taxation [307]. The limitation on the amount of bond financing of solar energy facilities is clear in the first case. Solar energy facilities must compete with other public needs for a limited source of funds to be received through issuing bonds. States that have this limitation; but are interested in encouraging the use of solar energy, can either repeal the provisions creating the limitation, or make special allowances for solar energy facilities. In the second case, if a municipality has a dollar limit on its power to tax and requires all the funds it collects to pay for general 
governmental expenditures, it will not be able to use its taxing power to raise sufficient funds to meet the bond payment obligations. Nevertheless, many courts have allowed municipalities to circumvent this limitation [308].

Because states do not have a great deal of funds to use for this type of program [309], a state's grant program will not be as effective as a federal level program. Some grant programs have been extended on the state level [310]. The major role of the state in federal grant incentive programs is to administer funds provided by the Federal Government.

\subsubsection{Summary}

Government transfer incentives have generally been limited in scope and directed toward technology demonstration. Large-scale programs directed at commercialization of solar energy technologies have not yet been attempted [311]. Despite the high costs and less equitable effects of grants, people seem to prefer this type of incentive. The potential legal impediments are far from insurmountable and can be avoided by careful fashioning of a grant program. The maximum benefits will probably be obtained by a grant program that is funded by the Federal Government and administered by a state government. 


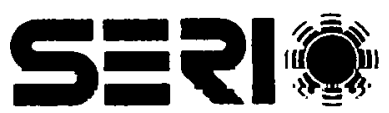




\section{SECTION 3.0 \\ GOVERNMENT ACTION INDIRECTLY APFECTING THE FNANCING AND AVAILABIITY OF SOLAR ENERGY TECHNOLOGIES}

This section deals with governmental financial activities that have significant effects on the commercialization of solar energy technologies, although the influence on the solar energy industry may not be as obvious as direct financial incentives to private purchasers, manufacturers of solar energy equipment, and private lending institutions.

\subsection{ELIMINATING OR REDUCING FINANCIAL INCENTTVES BENEPITING COMPETI- TIVE ENERGY SOURCES}

\subsubsection{Effects of Incentives to Competing Energy Sources}

The commercialization of solar energy technologies is significantly affected by government policy decisions concerning nonsolar energy sources [312]. The U.S. Government has traditionally followed a policy of making energy available at relatively low costs. This course of action has the advantage of stimulating economic growth and contributing to such amenities as heating and cooling of buildings and transportation [313].

The low-cost energy policy has been achieved by providing a number of incentives, mostly financial, to a number of energy sources. Artificially low prices for favored forms of energy will stunt the development of competing sources of energy. Since solar energy has not received the financial impetus of other forms of energy, its development is not as advanced as it would be under a competitive market situtation [314].

As nonsolar energy sources become more scarce or less desirable, the development of solar energy technologies can be encouraged by eliminating the monetary incentives going to nonsolar energy technologies. The remaining sections of this paper will briefly identify the monetary incentives that are currently being extended to the major nonsolar energy technologies and which could be eliminated or reduced.

There are no indications of legal impediments to this sort of deregulation, as long as government entities do not impair existing contracts they have entered into, in the deregulated industry. The public purpose reasons for enacting financial incentives for some conventional energy sources may no longer exist because of the detrimental effects they are having on society. If this is true, the Constitution may require deregulation of some energy technologies. In most cases, deregulation can be accomplished by amending the Internal Revenue Code.

Total and immediate deregulation of nonsolar energy technologies is not recommended because it would create a hardship on a large number of people and severely shock our economy; deregulation would be more beneficial if it were carried out over a long period of time.

\subsubsection{Financial Incentives to the Oil Energy Industry}

Oil is, by far, the greatest recipient of financial incentives, accounting for about $54 \%$ of total governmentul energy vutlays [315]. 
Financial incentives to the oil energy industry can be divided into two major categories: (1) exploration and production, which includes the search for, recovery, and transportation of crude oil and natural gas (most nonassociated natural gas is produced by oil companies) [316]; and (2) refinement and production of the crude oil into petroleum products and distribution for sale [317].

The major incentive used to stimulate oil production is the percentage depletion allowance [318]. Depletion is the exhaustion of supply of a wasting asset (oil) which diminishes the value of the remaining deposit [319]. A percentage of this depletion is allowed to be deducted from a company's income tax liability. Government allowance for this incentive between 1954 and 1976 has been about $\$ 37.5$ billion [320]

Another significant incentive is intangible drilling expenses [321]. This incentive allows an oil company to deduct from income taxes a portion of the expenses used in preparing and maintaining drilling sites [322]. Intangible drilling expenses resulted in about $\$ 7$ billion of lost revenue from 1953 to 1976 [323].

The Emergency Petroleum Allocation Act of 1973 is an incentive nominally directed at, increased oil exploration and production, and in effect provides an incentive to import foreign oil [324]. Under this Act, a two-tier price system was set up for old and new oil or stripper oil. Price incentives for stripper oil, incentives for new oil, and disbursement subsidies for tankers and pipelines were estimated to be $\$ 30$ billion from 1921 to 1976 [325].

The only other area where major financial incentive reductions could be made is in traditional services, such as maintenance and dredging of harbors and waterways to allow for oil transportation. This incentive has cost the government about $\$ 4.7$ billion in lost revenues [326].

\subsubsection{Financial Incentives to the Gas Industry}

It should be kept in mind that government expenditures for production and transmission of synthetic fuels may also benefit natural gas companies [327].

The major incentives for the natural gas industry are intangible drilling expenses and percentage depletion allowances, which are similar to those enjoyed by the oil industry [328]. They cost the government $\$ 11$ billion in lost revenue and make up $75 \%$ of federal expenditures to the natural gas industry [329].

The only other natural gas incentive significant enough to affert the snlar energy industry are wellhead price controls. The Natural Gas Act of 1938 will not allow interstate gas to be sold at intrastate prices [330]. This Act causes the price of natural gas to be held artificially low in some interstate sales. The price difference of all interstate sales has resulted in a subsidy of about $\$ 3.5$ billion to purchasers of natural gas between 1960 and 1975 [331].

Financial incentives from the Federal Government to the gas industry are estimated at $\$ 15.1$ billion or $12 \%$ of energy outlays [332]. The Natural Gas Poliey Aot of 1978 has provisions to deregulate the natural gas industry, thereby reducing these incentives [333]. 


\subsubsection{Financial Incentives to the Coal Industry}

About $66 \%$ of United States mined coal resources have been used by utilities to generate electricity and about $32 \%$ have been used by industry [334]. The two major incentives offered by the Federal Government have been the percentage depletion allowance and expenditures for research [335]. The depletion allowance accounted for about $\$ 3$ billion of government subsidy for the period of 1954 to 1976 [336]. Research on improved methods of mining has resulted in about $\$ 1.4$ billion in federal subsidies [337].

The cost of this incentive is the lowest for the five major energy technologies, with expenditures totaling about $\$ 6.8$ billion, only $5 \%$ of total energy outlays [338]. More important than reducing or eliminating financial incentives to coal is avoidance of further incentives. The Power Plant and Industrial Fuel Use Act extends further monetary incentives to the coal industry [339]. This will certainly affect the commercialization of solar energy technologies.

\subsubsection{Financial Incentives to the Hydroenergy Industry}

The Federal Government has been responsible for building and regulating hydroelectric plants which produce $47 \%$ of hydroelectric generation [340]. In those facilities, the government "has acted as a market entity at each step of the production-consumption cycle, from ownership of the primary facilities of production through delivery to the consumer. Therefore, $100 \%$ of the incentives used to stimulate hydroenergy production would be categorized as market activity" [341]. As a result, the incentives must be artifically separated by estimating rate of return on investment or making comparisons with private industries [342]. These calculations have derived estimates of $\$ 17.5$ billion and $\$ 9.2$ billion as the value of federal incentives [343]. This would give hydroenergy about $10 \%$ of total energy outlays [344].

\subsubsection{Financial Incentives to the Nuclear Energy Industry}

The Federal Government has also been pervasively involved in developing nuclear energy [345]. Nuclear plants are responsible for about $9 \%$ of generated electric power [346].

Over $70 \%$ of the government cost for this incentive has gone to fund research and development. This figure has been estimated at $\$ 13.2$ billion between 1950 and 1976 [347]. Most of these research and development projects have been directed toward determining the potential for nuclear power [348]. The majority of the remaining costs have been subsidies for enrichment plants ( $\$ 1.7$ billion) and regulatory activities ( $\$ 1.2$ billion) [349].

It is impossible to compute the total costs of incentives that have been extended to the nuclear energy industry, because a number of federal uranium policies and the liability insurance provided to the industry are not quantifiable [350]. The Price-Anderson Act of 1957 was enacted to insure the industry against the risks associated with nuclear energy production [ 351$]$. This cost could be quite high because of the risk involved, which would determine the value of the insurance premium in the private sector.

The quantifiable costs to the government for the nuclear energy industry are estimated to be between $\$ 15.3$ billion and $\$ 17.1$ billion, or about $13 \%$ of total energy outlays [352]. 


\subsubsection{Summary}

Government policies directed toward increasing the energy market share of the five energy sources discussed in this section, will have an indirect effect on the energy market share of solar energy. If solar energy is a desirable energy source, it should be given a larger share of the energy market. One means to accomplish this is by eliminating or reducing the governmental incentives currently being extended to less desirable forms of energy.

\subsection{GOVERNMENT ACTIONS TO ENSURE OPERATION OF SOLAR ENERGY EQUIPMENT}

Two risks that lenders and purchasers identify with solar energy facilities are workability and system life. Poorly constructed or improperly installed systems could give the entire industry a bad reputation and slow the commcrcialization of solar energy [35.3] .

The optimal way to overcome the problem in manufacturer or dealer warranties is to allocate the risk of failure or underperformance before sale. Generally these warranties are not being offered because of the experimental and particularized nature of solar entergy systems where performance may depend on location, position, shape of the building, and other characteristics that are unique to each structure [354].

The most important consideration that lenders have in deciding whether or not to provide capital to a borrower is the risk of not having the borrowed funds returned. Risk determines interest rates, and whether a loan will be provided at all to someone seeking a loan [355].

Consumers (including homeowners, business owners, and builders) are also conscious of risk. The lack of guarantees on performance of a solar energy facility will result in the consumer imputing a high risk cost with the price of the facility. More consumcrs will buy solar energy facilities if risk costs are reduced.

The government will be offering an indirect financial incentive if it can reduce these risk costs, by standards for construction and operation of solar energy facilities or governmental requirements for manufacturers and builders to warrant the performance of the installed facilities. There seems to be little question that the government could require either of these approaches if public health, safety, and welfare demandcd it. Standards for cunstruction and operation are more practical, because the experimental nature of solar energy systems make performance prediction for all situations almust inupussible. Performance warranties may also be of little value because the solar energy industry contains a large number of small firms with few economic resulres to back the warranties, even if they were required [356].

The Department of Housing and Urban Development has a set of standards that must be followed for its solar energy building program [357]. These standards could be improved and design manuals could be prepared for a number of building types in each category of solar energy technology.

An effective standards program would probably generate lender and consumer confidence in reliability and performance of solar energy systems, decrease the likelihood of disreputable manufacturers, and allow consumers to specify their solar energy systems [358]. 


\subsection{GOVERNMENT SPONSORED EDUCATION, RESEARCH, AND DEVELOPMENT PROGRAMS}

Ignorance of the advantages and reliability of solar energy technologies is one reason that lenders place high risk values on financing solar energy facilities, and why some consumers do not purchase solar energy systems [359]. Lenders and consumers of ten lack technical information on the operation and reliability of solar energy facilities [360]. Because lenders do not consider the full value of a solar energy system in solar lending policy, consumers are forced to make higher down payments [361]. Consumers who cannot make the large down payment will be precluded from buying a solar energy facility. The government could eliminate some of these risks by providing for a practical technical solar energy education program [362].

For example, lenders and consumers are of ten unaware of the importance of life cycle costing when determining the economic feasibility of solar energy systems. Life cycle costing is an estimation of the total costs of solar and conventional energy systems over the lives of the systems, discounted back to the present. The system that has the lowest discounted cost is the true lowest cost investment [363]. The two most important cost considerations are initial costs and costs of operation. Usually the initial costs of solar energy facilities, especially active systems, far outweigh the initial costs of conventional energy systems [364]. On the other hand, operating costs of conventional energy systems are greater than solar energy systems because conventional systems use larger amounts of high-priced fuels [365]. This can be a difficult calculation because of the mathematics involved and the unpredictability of future events and prices [366]. As a result, most consumers and lenders base their decisions on less accurate cost comparisons, such as initial cost comparisons. The government could provide information on life cycle costing to lenders and consumers to improve the quality of their decisions on energy facilities. This program should include information and ways to compute life cycle costs, as well as the advantages of life cycle costing [367]. The Federal Government has awarded some construction contracts on the basis of life cycle costing [368], and may require use of life cycle cost analysis for government buildings in the National Energy Act [369]. Some states use life cycle costing for government buildings, and a few states require use of life oyole costing when evaluating bids for government purchases [370].

Lenders and consumers may not be aware of the loan incentives available to help finance the construction of solar energy facilities [371]. The government could include this information in an education program.

A government education program could be administered by existing agencies, including federal and state energy related agencies [372]. Costs of the program would probably be low since no subsidies would be involved [373].

Where solar energy technologies are sufficiently underdeveloped to justify apprehension by lenders and consumers, research and develnpment operations can be conducted and the resul ting information disseminated.

\subsection{GOVERNMENT DEMONSTRATION AND PROCUREMENT PROGRAMS}

In a government demonstration program, the government encourages the display of solar energy systems by sharing part of the costs of installing the system in private structures. In a procurement program, which is similar in effect, the display systems are installed in government buildings [374]. "Highly visible, widely publicized demonstrution 
projects can be used both to establish the technical and economic feasibility of solar systems in specific applications, and as public showcases which enable potential consumers to see what a solar system is like and how it operates without taking any personal risk" [375]. If the consumers participating in the program are satisfied with their solar energy facilities or if consumers who view government solar energy facilities are satisfied with those facilities, they may use the systems in subsequent building projects or influence the energy choices of other consumers. Another advantage of these programs is that they stimulate growth in the solar energy industry, since systems will be sold for demonstration and procurement purposes [376].

There seem to be no major legal barriers to carrying out demonstration or procurement programs. The Federal Government is currently conducting an extensive demonstration program through the Department of Housing and Urban Development [377]. The National Energy Conservation Policy Act provides for $\$ 100$ million for a solar energy procurement program [378]. The procurement program requires the use of life cycle costing in its decision-making process to promote the use of lifc eycle costing [379]. An additional $\$ 98$ million has been approved by the conference committee for procurement of photovoltaic systems [380].

Demonstration and procurement programs to display and test solar energy facilities act as indirect financial incentives by reducing risk costs that consumers and lenders associate with the solar energy industry, and by stimulating growth in the industry.

\subsection{GOVERNMENT FINANCIAL NCENTIVES AS DISINCENTTVES}

Legislative consideration of financial incentives to the solar energy industry can act as a disincentive to the commercialization of solar cnergy technologies because of the lag time between proposal of a financial incentive and its cnactment.

The slow pace of legislutive consideration may impede growth of the solar energy industry "by making people who might otherwise buy a colar cnergy devite wult for enactment of some kind of incentive" [381]. Many solar company executives attributed diminished sales to the potential tax incentives in the National Energy Act considered in Congress.

Our governmental system of checks and balances protects against arbitrary decision making. The obvious disadvantage is the long time period required to comply with the checks and balances [382]. An appropriate solution would be to reduce the bill consideration period as much as possible by giving solar energy bills high priority in the devisionmaking process, and to appeal to policy makers to refrain from using delaying tactics for political reasons extraneous to the energy bill. 


\section{SECTION 4.0}

\section{CONCLUSIONS}

The United States is being forced to seek out alternate sources of energy to replace diminished conventional sources. Solar energy has a number of characteristics that make it a desirable replacement.

A financial incentives program is required to reduce the difficulties of commercialization that confront new technologies. Many incentives can contribute to this goal without confronting unique legal or institutional impediments which cannot be remedied by preventive legislation. 


\section{SEPI}




\section{SECTION 5.0}

\section{REFERENCES}

1. L. Solomon and F. Riesmeyer, The Development of Alternate Energy Sources: A Legal and Policy Analysis, 30 Okla. L.Rev. 319 (1977) [hereinafter cited as The Development of Alternate Energy Sources].

2. P. Fannin, Solar Energy: Overcoming the Barriers, 23, No. 7 Ariz. Bus. 3 (1978).

3. National Energy Act, 1 Ad Hoc Committee on Energy, U.S. House of Representatives, 95th Congress; 1 st Session 7 (Rpt. No. 95-543, 1977).

4. The Development of Alternate Energy Sources, supra note 1 at 319.

5. See generally T. Consroe, F. Glaser. and R. Shaw, Potential Evironmental Impacts of Solar Heating and Cooling Systems (Environmental Protection Agency, 600/776-014, 1976).

6. The Development of Alternate Energy Sources, supra note 1 at 321 .

7. Mitre Corp., Solar Energy, A Comparative Analysis to the Year 20206 (Energy Research and Development Administration E-(4918)-2322, 1978).

8. Id. at 12.

9. MeCulloch v. Maryland, 17 U.S. (4 Wheat.) 316, 404-06 (1819).

10. U.S. Const. Art. I, $\$ 8$, cl. 3 and cl. 18.

11. U.S. Const. Art. I, \$ 8, cl. 1, U. S. Const.

12. U.S. Const. Art. I, $\$ 8, \mathrm{cl} .1$.

13. Stafford v. Wallace, 258 U.S. 495 (1922).

14. Heart of Atlanta Hotel, Inc., v. United States, 379 U.S. 241, 255 (1964).

15. E.g., Katzenbach v. McClung, 379 U.S. 294 (1964).

16. See Powell v. United States Cartridge Co., 339 U.S. 497, 512-15 (1949).

17. See United States v. Wrightwood Dairy Co., 315 U.S. 110 (1942).

18. See Wickard v. Filburn, 317 U.S. $111,126-29$ (1942).

19. Id.

20. MeCulloch v. Maryland, 17 U.S. (4 Wheat) 316 (1819).

21. Id. at 421. 
22. U.S. Const. Art I, $\$ 8$ cl. l; United States v. Doremus, 249 U.S. 86, 93 (1919).

23. See McCray v. United States, 195 U.S. 27 (1904); Steward Machine Co. v. Davis, 301 U.S. 548 (1937).

24. Helvering v. Davis, 301 U.S. 619,640 (1937).

25. E.g., United States v. Kariger, 345 U.S. 22 (1953); Sonzinsky v. United States, 300 U.S. 606 (1937).

26. United States v. Butler, 297 U.S. 1, 67 (1936).

27. Id. at 64-65.

28. E.g., Steward Machine Co. v. Davis, 301 U.S. 543 (1937).

2y. Marberry v. Madison, 5 U.S. (1 Cranch) 137, 176 (1803).

30. U.S. Const. Amend. V. No person shall ... be deprived of life, liberty, or property, without due process of law; nor shall private pronerty he taken for public usc, without just compensation.

31. Nebbia v. New York, 291 U.S. 502, 537 (1934).

32. See Grocers Dairy Co. v. McIntyre, 377 Mich. 71, 138 N.W.2d 767 (1966).

33. E.g., Rudder v. United States, 226 F.2d 51 (D.C. Cir. 1955); Stock v. State, 526 P.2d 3 (Alaska 1974).

34. E.g., Papachristou v. City of Jacksonville, 405 U.S. 158 (1972).

35. E.g., Bolling v. Sharpe, 347 U.S. 497 (1954).

36. Id. at $499-500$.

37. South Terminal Corp. v. Environmental Protection Agency, 504 F.2d 646, 678 (1st Cir. 1974).

38. E.g., Stipe v. United States, 337 F.2d 818, 821 (1964); Goldblatt v. Hempstead, 369 U.S. 590, 92 (1962).

39. Michelman, Property, Utility, and Fairness: Comments on the Ethical Foundation of "Just Compensation" Law, 80 Harv. L. Rev. 1165,1184 (1967).

40. Miller v. Board of Public Works, 195 Cal. 477, 234 P. 381 (1925), error dismissed, 273 U.S. 781 (1926).

41. Southwestern Oil Co. v. Texas, 217 U.S. 114 (1910).

42. State ex rel. Webster v. Superior Court of King County, 67 Wash. 37, 120 P. 861 (1912).

43. E.g., Stock v. State, 526 P.2d 3 (Alaska 1974). 
44. E.g., Barnwell, Inc. v. Sun Oil Co., 249 Miss. 398, 162 So.2d 635, 641 (1964).

45. E.g., Leiter Minerals, Inc. v. California Co., 241 La. 915, 132 So.2d 845, 851-52 (1961).

46. E.g., State v. Elmwood Terrace, Inc., 85 N.J. Super. 240, 204 A.2d 379 (1964). S. White, Santa Clara, California, Community Center, Commercial Solar Demonstration, Legal Alternatives, Implications, and Financing of Solar Heating and Cooling by a Municipal Corporation 9-11 (Energy Research and Development Administration, San/1083-76/1, 1976) [hereinaf ter cited as Santa Clara Study].

47. See pp. 1-2 supra.

48. E.g., Marrs v. City of Oxford, 32 F.2d 134 (8th Cir. 1929).

49. Mills and Woodson, Energy Policy: A Test for Federalism, 18 Ariz. I. Rev. 405, 414-15 (1976).

50. See pp. 1-2 supra.

51. Union Refrigerator Transit Co. v. Lynch, 18 Utah 378, 55 P. 639, 640 (1898).

52. Id.

53. State ex rel. State Reclamation Board v. Clausen, 110 Wash. 525, 188 P. 538, 54041 (1920).

54. J. Nowak, R. Rotunda, and J. Young, Constitutional Law (1978).

55. E.g., Albritton v. Winona, 181 Miss. 75, 178 So. 799 (1938), appeal dismissed, 303 U.S. 627 (1938).

56. State ex rel. Pierce v. Gowdy, 62 Mont. 119, 203 P. 1115, 1117 (1922); Robinson v. City of Norfolk, 108 Va. 14, 60 S.E. 762, 764 (1908).

57. E.g., State v. Kartus, 230 Ala. 352, 162 So. 533 (1935).

58. Gibbons v. Ogden, 22 U.S. (9 Wheat.) 1 (1824).

59. See pp. 1-2 supra.

60. U.S. Const. Art. VI, $\$ 2$.

61. MeCulloch v. Maryland, 17 U.S. (4 Wheat.) 316, 405 (1819).

62. R. Bezdek, J. Margolin, T. Sparrow, G. Sponsler, A. Ezra, R. Spongberg, A. Miller, F. Meeker, E. Roseman, and M. Misa, Analysis of Policy Options for Acceleruting Commercialization of Solar Heating and Cooling Systems 123-47 (George Washington University, 1977) (hereinafter cited as Policy Options]; Office of Technology Assessment, l Application of Solar Technology to Today's Energy Needs 86-89 (1978) [hereinafter cited as OTA Study]. See also Johnson, State Approach to Solar Legislation: A Survey, Solar L.R. 55 (1979). 
63. U.S. Const. Art. 1, $\$ 10$, cl. 1. No State shall ... pass any . . Law impairing the Obligation of Contracts.

64. South Terminal Corp. v. Environmental Protection Agency, 504 F.2d 646, 680 (1st Cir. 1974).

65. Home Bldg. \& Loan Ass'n. v. Blaisdell, 290 U.S. 398, 428-31 (1934).

66. South Terminal Corp. v. Environmental Protection Agency, 504 F.2d 646, 680 (1st Cir. 1974).

67. Santa Clara Study, supra note 46 at 3-5.

68. City of Denver v. New York Trust Co., 229 U.S. 123 (1913); Madera Waterworks v. City of Madera, 228 U.S. 454 (1913).

69. Santa Clara Study, supra. note 46 , at $3 \mathrm{nn} .21$ and 22.

70. Id. at 3.

71. Id. at $3-4$.

72. Id. at 3.

73. E.g., Koch v. Yunich, 533 F.2d 80, 86 (2d Cir 1976); State v. Adamany, 64 Wis.2d 280,219 N.W.2d 274, 281-84 (1974).

74. See generally M. Forkosch, Constitutional Law (1963).

75. Many state constitutions have a Bill of Rights that is more restrictive of governmental powers than the Federal Constitution.

76. Asphalt Paving Co. v. Board of County Commr's., 162 Colo. 254, 425 P.2d 289 (1967).

77. Lewis v. Nashville Gas \& Heating Co., 162 Tenn. 268, 40-S.W.2d 409 (1931).

78. Vandalia R. Co. v. Schnull, 188 Ind. 87, 122 N.F. 227 (1919), rev'd on other gruuinds, 255 U.S. 113 (1921).

79. Kalbfell v. City of St. Louis, 357 Mo. 986, 211 S.W.2d 911, 916-17 (1948).

80. City of Golden v. Ford, 141 Colo. 427, 348 P.2त 954 (1960).

81. Town of Newcastle v. Toomey, 329 P.2d 264, 266-67 (Wyo. 1958).

82. City of Jackson v. Freeman-Howie, Inc., 239 Miss. 84, 121 So.2d 123 (1960).

83. Zucht v. King, 260 U.S. 174 (1922).

84. Johnson v. Genesee, 232 F.Supp. 567, 571-72 (E.D. Mich. 1964); Phoenix City v. Alabama Power Co., 239 Ala. 547, 195 So. 894, 897 (1940). 
85. Jenner v. City Council, 164 Cal. App.2d 490, 331 P.2d 176 (1958).

86. Malone v. Williams, 118 Tenn. 390,103 S.W. 798 (1907).

87. Briggs v. Elliot, 98 F.Supp. 529 (E.D.S.C. 1957), vacated on other grounds, 342 U.S. 350 (1952).

88. City of Phoenix v. Arizona Sash, Door, and Glass Co., 80 Ariz. 100, 293 P.2d 438 (1956).

89. E.g., A.R.S. $\$ 43-123.37$ (c) (Supp. 1957-1977); Code of Ala. ch. $18 \$ 40-18=15(a)(17)$ (Cum. Supp. 1977).

90. Federal Energy Administration, II Solar Heating and Cooling of Buildings (SHACOB), Commercialization Report, Opinions and Strategies, part A, 101 (1977) [hereinafter cited as SHACOB]; Policy Options, supra note 62 at 51; Arthur D. Little, Inc., Residential Solar Heating and Cooling Constraints and Incentives. A review of the Literature 57 (United States Department of Housing and Urban Development, PB-258 238, 1976) [hereinaf ter cited as Constraints and Incentives].

91. Id. at 101-02; Policy Options, supra note 62 at 51-52.

92. Id.; Energy Research and Development Administration, Interim Policy Options for Commercialization of Solar Heating and Cooling Systems $7(77-62,1977)$ [hereinaf ter cited as Interim Policy Options].

93. Constraints and Incentives, supra note 90 at 57.

94. Policy Options, supra note 62 at 51.

95. C. Breeding, F. Burke, and A. Burton, Income Taxation of Natural Resources, ॥थ1 208-09, 1509, 2905 (1975) [hereinafter cited as Natural Resource Taxation], Battelle Pacific Northwest Laboratories, An Analysis of Federal Incentives Used to Stimulate Energy Production 178, 213-16 (United States Department of Energy, PNL-2410, 1978) [hereinafter cited as Federal Incentives] .

96. SHACOD, supra notc 91 at 102 .

97. Id.

98. Constraints and Incentives, supra note 90 at 57; Federal Incentives, supra note 95 at 11.

99. W. Thomas, A. Miller, and R. Robbins, Overcoming Legal Uncertainties About Use of Solar Energy Systems 80 (American Bar Foundation 1978) [hereinafter cited as Overcuining Legal Uncertaintics].

100. Id.

101. Natural Resource Taxation, supra note 95, ฯथ 1208-09, 1509, 2905,

102. E.g., Policy Options, supra note 62 at 127; Commerce Clearing House, Inc., 38 State Tax Review No. 36, 1-3 (1977). 
103. Policy Options, supra note 62 at 51-52.

104. SHACOB, supra note 90 at 97; Contraints and Incentives, supra note 90 at 57; Policy Options, supra note 62 at 50.

105. Constraints and Incentives, supra note 90 at 57.

106. Id. at 58.

107. SHACOB, supra note 90 at 98 .

108. Constraints and Incentives, supra note 90 at 57; Policy Options, supra note 62 at 50.

109. Id. SHACOB, supra note 90 at 98.

110. SHACOB, supra note. 90 at 98 .

111. Id. at 100 .

112. Id.

113. Id. at 98.

114. Policy Options, supra note 62 at 50.

115. SHACOB, supra note 90 at 103 .

116. Iก.

117. Id. at 119.

118. See Natural Kesource Taxation, supra note 95 at 11 1520-23 (investment tax credits allowed for the oil and gas industry).

119. SHACOB, supra note 90 at 119.

120. Interim Policy Options, supra note 92 at 7; SHACOB, supra note 90 at 104.

121. OTA Study, supra note 62 at 75; Constraints and Incentives, supra note 94 at 59.

122. OTA Study, supra note 62 at 75.

123. E.g., I.R.C. $\$ \$ 31$ et. seq., 6401 et. seq.; Natural Resouroe Tnxntinn, supra note 95 uL ขI 1520-23.

124. Interim Policy Options, supra note 92 at 6; Federal Incentives, supra note 95 at 12.

125. E.g., Policy Options, supra note 62 at 127-29.

126. The five acts comprising the National Energy Act include: Energy Tax Act of 1978, Pub. L. No. 95-618, 92 Stat. 3174 (1978). National Energy Conservation Policy Act of 1978, Pub. L. No. 95-619, 92 Stat. 3206 (1978). Natural Gas Policy Act of 1978, 
Pub. L. No. 95-621, 92 Stat. 3350 (1978). Power plant and Industrial Fuel Use Act of 1978, Pub. L. No. 95-620, 92 Stat. 3289 (1978). Public Utilities Regulatory Policies Act of 1978, Pub. L. No. 95-617, 92 Stat. 3117 (1978).

127. Energy Tax Act of 1978, Pub. L. No. 95-618, $\$ 101,92$ Stat. 3174 (1978) (to be codified at 26 U.S.C. $44 \mathrm{C})$.

128. Id. at $\$ 301$ (to be codified at 26 U.S.C. 46 ).

129. OTA Study, supra note 62 at 75; SHACOB, supra note 90 at 119.

130. Constraints and Incentives, supra note 90 at 59.

131. OTA Study, supra note 62 at 75-78.

132. SHACOB, supra note 90 at 119 .

133. Id. at 105.

134. See id. at 107 .

135. OTA Study, supra note 62 at 75.

136. C.f., Grocers Dairy Co. v. McIntyre, 377 Mich. 71, 138 N.W.2d 767 (1966).

137. New Colonial Ice Co. v. Helvering, 292 U.S. 435, 440 (1934).

138. Tax Reform Act of $1969 \$ 704,26$ U.S.C. $\$ \$ 169,187$ (1978); Constraints and Incentives, supra note 90 at 59.

139. Policy Options, supra note 62 at 55.

140. SHACOB, supra note 90 at 105 .

14l. E.g., A.R.S. $\$ 43-123.37$ (a) (Supp. 1957-1977); Kan. Stat. Ann. ch. $79 \$ 32,168$ (1977).

142. H. Peterson, The Impact of Tax Incentives and Auxiliary Fuel Prices on the Utilization Rate of Solar Energy Space Conditioning 10 (National Science Foundation, PB-252 538, 1976) [hereinafter cited as NSF Study].

143. Santa Clara Study, supra note 46 at $30-32$.

144. M. Willatt, Constitutional Restrictions on Use of Public Money and Public Credit, 38 Tex. B.J. 413 (1975).

145. K. Dam, The American Fiscal Constitution, 44 U. Chi. L.Rev. 271, 291 (1977).

146. Santa Clara Study, supra note 46 at $30-48$.

147. Id. 
148. M. Willatt, Constitutional Restrictions on Use of Public Money and Public Credit, 38 Tex. B.J. 413 (1975); T. Arthur and J. Richardson, Financing of Pollution Control Facilities Through Tax Exempt Bonds, 58 Chi. B. Rec. 248-49 (1977).

149. Santa Clara Study, supra note 46 at 34 .

150. Id.

151. Id. at 35 .

152. M. Willatt, Constitutional Restrictions on Use of Public Money and Public Credit, 38 Tex. B.J. 413-22 (1975).

153. I.R.C. $\$ 103(b)$.

154. I.R.C. $\$ 103(\mathrm{~b})(4)(5)(6)$. Among the tax exempt projects are residential property for family units, spurts facilíties, convention or trade show facilities, airports, docks, wharves, mass communicating facllities, parking fncilities, sewage or vulid waste disposal facilities, facilities for local furnishing of electric energy or gas (potentially applicable to some solar energy facilities), air and water pollution control facilities, and facilities for furnishing water.

155. I.R.C. $\$ 103(\mathrm{~b})(4)(\mathrm{E})$.

156. I.R.C. $\$ 103(\mathrm{~b})(4)(\mathrm{F})$.

157. MeCulloch v. Maryland, 17 U.S. (4 Wheat.) 316,431 (1819).

158. Pollock v. Farmers' Loan and Trust Co., 157 U.S. 429, 583-86 (1895).

159. K. Dam, The American Fiscal Constitution, 44 U. Chi, L. Rev. 271, 291 n. 97 $(1977)$.

160. Santa Clara Study, supra note 46 at $40-42$.

161. Federal Const. Co. v. Ensign, 59 Cal. App. 200, 209, 210 P. 536, 540 (1922).

162. Santa Clara Study, supra note 46 at $42-43$.

163. Id.

164. Federal Const. Co. v. Ensign, 59 Cal. App. 200, 208, 310 F. 536, 540 (1922).

165. Id.

166. Santa Clara Study, supra note 46 at 36 n. 380.

167. Id. at n.381.

168. Id. at 36 .

169. Id. at 43 n. 474-75. 
$\stackrel{11}{*=-1}$

170. Id. at 43.

171. Id.

172. OTA Study, supra note 62 at 78; Environmental Law Institute, Legal Barriers to Solar Heating and Cooling of Buildings 158 (United States Department of Energy, HCP/M2528-01, 1978) [hereinafter cited as Legal Barriers].

173. Legal Barriers, supra note 172 at 158.

174. Hattiesburg Grocery Co. v. Robertson, 126 Miss. 34, 655, 88 So. 4, 89 So. 369 (1921), error dismissed, 260 U.S. 710 (1923).

175. Legal Barriers supra note 172 at 158.

176. OTA Study, supra note 62 at 78-79.

177. Legal Barriers, supra note 172 at 162.

178. Overcoming Legal Uncertainties supra note 99 at 73.

179. U.S. Const. Art I, $\$ 9$, cl. 4.

180. Legal Barriers, supra note 172 at 159.

181. SHACOB, supra note 90 at 113.

182. See pp. 55-56 infra.

183. National League of Cities v. Usury, 426 U.S. 833 (1976).

184. Id.

185. SHACOB, supra note 90 at 115 ; Policy Options, supra note 62 at 52.

186. Legal Barriers, supra note 172 at $159-60$.

187. Id.

188. 11 New England L.Rev. 617, 618-20 (1976).

189. Legal Barriers, supra note 172 at 160.

190. See p. 8 supra.

191. Sce p. 15-17 supra.

192. Santa Clara Study, supra note 46 at 18-19; Overcoming Legal Uncertainties, supra note 99 at 79 .

193. Legal Barriers, supra note 172 at 160.

194. Nashville, C. \& St. L. Ry. v. Browning, 310 U.S. 362 (1940). 
195. E.g., Hellerstein v. The Assessor of Islip, 37 N.Y.2d 1, 371 N.Y.S.2d 388 (1975); Bettigole v. Assessors of Springfield, 343 Mass. 223, 178 N.E.2d 10 (1961).

196. E.g., 11 New England L.Rev. 617, 627-28. The uniformity clause in Tennessee's Constitution and statutes were eliminated subsequent to a state court holding that property tax classifications violated the uniformity clauses.

197. Legal Barriers, supra note 172 at 160.

198. A. Wallenstein, Barriers and Incentives to Solar Energy Development, Draft Report 11 (Northeast Solar Energy Center 1978) [hereinafter cited as Barriers and Incentives]; Legal Barriers, supra note 172 at 161.

199. NSF Study, supra note 142 at 77.

200. J. Due, The Nature and Structure of Sales Taxation, 9 Vand, L.Rev. 123, 12.3-2.4 (1956).

201. Halliburton Oil Well Cementing Co. v. Reily, 373 U.S. 64 (1963).

202. IU.

203. Id.

204. U.S. Const. Art. I, $\$ 9$, cl. 4.

205. See pp. 33-34 supra.

206. Henderson v. Department of Revenue, $30 \mathrm{nl.2d} \mathrm{451,197} \mathrm{N.E.2d} 18$ (1964). But see, State ex. rel. Otis Elevator Co., v. Smith, 357 Mo. 1055, 212 S.W.2d 580 (1948).

207. É.g., Ohio Bus Line Co. v. Bowers, 1 Ohio App.2d 122, 200 N.E.2d 688 (1964).

208. E.g., Detroit Edison Co. v. State, 298 Mich. 259, 298 N.W. 525 (1941); State ex. rel. Kansas rity Power and Light Co, v. Emith, 342 Mu. 75, 111 S.W.2d 513 (i938).

209. State Board of Tax Comm'rs of Indiana v. Juckson, 283 U.S. 527 (1931); Texas Co. v. Brown, 258 U.S. 466 (1922).

210. Fiorito v. Jones, 39 Ill.2d 531, 236 N.E.2d 698 (1968), appcaled, 40 Ill.2d 568, 272 N.E.2d 41 (1971).

211. Constraints and Incentives, supra note 90 at 60 .

212. Connecticut Light \& Power Co. v. Walsh, 134 Conn. 295, 57 A.2d 128 (1948).

213. Jones v. Gordy, 169 Md. 173, 180 A. 272 (1935).

214. Welsh v. Sells, 244 Ind. 423,192 N.E.2d 753 (1963).

215. OTA Study, supra note 62 at 80 .

216. Constraints and Incentives, supra note 90 at 60 , NSF Study, supra note 142 at 69. 
217. Interim Policy Options, supra note 92 at 10; Policy Options, supra note 62 at 62 ; SHACOB, supra note 90 at 107.

218. Interim Policy Options, supra note 92 at 10-11; SHACOB, supra note 90 at 107-08, 110.

219. Id.

220. SHACOB, supra note 90 at 108 .

221. 15 U.S.C. $\$ 636$ et. seq. (1976 \& Supp. 1978).

222. SHACOB, supra note 90 at 108 .

223. Id.

224. Policy Options, supra note 62 at 62 .

225. SHACOB, supra note 90 at 108 .

226. National Defense Education Act, Title I $\$ 137(a)(1), 20$ U.S.C. $\$ 421$ (1974 \& Supp. 1978).

227. Housing and Urban Development Act of 1968, Title II $\$ 201(a), 12$ U.S.C. $\$ 1715 z-1$ (Supp. 1978).

228. OTA Study, supra note 62 at 87.

229. Id.

230. Id.

231. National Energy Conservation Policy Act of 1978, Pub. L. No. 95-619, 92 Stat. 3206 (1978).

232: Id. at $\$ 244$.

233. Id. at $\$ 242$.

234. Policy Options, supra note 62 at 63.

235. Interim Policy Options, supra note 92 at 10.

236. Policy Options, supra note 62 at 65.

237. OTA Study, supra note 62 at 86 .

238. Id. at 88.

239. Id. at 88-89; Constraints and Incentives, supra note 90 at 62 ; Policy Options, supra note 62 at 66 .

240. SHACOB, supra note 90 at 111 . 
241. Policy Options, supra note 62 at 67.

242. Id.

243. SHACOB, supra note 90 at 111 .

244. Id.; Policy Options, supra note 62 at 66.

245. Policy Options, supra note 62 at $66-67$.

246. National Housing Act, 12 U.S.C. $\$ 1707$ et seq. (1969 \& Supp. 1978).

247. OTA Study, supra note 62 at $88-89$.

248. Rural Electrification Act of 1936 ch. 77.6, $\$ \$ 2,4(f), 7$ U.S.C. $\$ 907$ (1964 \& Supp. 1978).

249. 15 U.S.C. $\$ 631$ et seq. (1976 \& Supp. 1978).

250. Bureau of National Affairs, Inc., 241 Energy Users Report 26-27 (0093$0261 / 78 / 500.50,1978)$.

251. Id.

252. SHACOB, supra note 90 at 111 .

253. Energy Conservation and Production Act, Title IV $\$$ D, 42 U.S.C. $\$ 6881$ (1974 \& Supp. 1978); OTA Study, supra note 62 at 111 .

254. OTA Study, supra note 62 at 88 .

255. See p. 44 supru.

256. National Energy Conservation Policy Act. Pub. L. No. 95-619, $\$ 241,92$ Stat. 3206 (1978).

257. Id. at $\$ 247$.

258. The Development of Alternate Energy Sources, supra note 1 at 341-42.

259. D. Barrett, P. Epstein, \& C. Haar, Home Mortgage Lending and Solar Energy 27 (United States Department of Housing and Urhan Development, 1977) [hcrcinafter cited as Home Mortgage Lending].

260. Id.

261. Id.; OTA Study, supra note 62 at $88-89$.

262. Id.

263. Home Mortgage Lending, supra note 259 at 27.

264. Id. 
265. National Energy Conservation Policy Act of 1978 Pub. L. No. 95-619, \$\$ 242-246, 92 Stat. 3206 (1978).

266. 12 U.S.C. $\$ 1461$ et. seq. (1969 \& Supp. 1978).

267. Legal Barriers, supra note 172 at 76.

268. Id. 12 U.S.C. $\$ 1461(c)(1969$ \& Supp. 1978).

269. Legal Barriers, supra note 172 at 76 .

270. 12 U.S.C. $\$ 1461$ (c) (1969 \& Supp. 1978).

271. Legal Barriers, supra note 172 at 77.

272. 42 U.S.C. $\$ 5511$ (1977 \& Supp. 1978).

273. 12 U.S.C. $\$ 1464$ (1969 \& Supp. 1978).

274. Legal Barriers, supra note 172 at 81 .

275. Id. at 82 .

276 Id.

277. Id.

278. See R. Stewart, Pyramids of Sacrifice? Problems of Federalism In Mandating State Implementation of National Energy Policy, 86 Yale L.J. 1196 (1977).

279. R. Wallick \& W. Montalto, Symbiosis or Domination: Rights and Remedies Under Grant-Type Assistance Programs, 46 Geo. Wash. L. Rev. 159, 162-65 (1978).

280. United States v. San Francisco, 310 U.S. 16 (1940).

281. E.g., Burke v. Southern Pacific R.R. Co., 234 U.S. 669 (1914),

282. SHACOB, supra note 90 at 93,94 .

283. Interim Policy Options, supra note 92 at 11.

284. W. Taylor, M. Sklar, \& S. Zehner, Legal Issues In Revenue Sharing, 8 Clearinghouse Rev. 18 (1974).

285. Id. at 18-19.

286. SHACOB, supra note 90 at 95; Policy Options, supra note 62 at 49.

287. Policy Options, supra note 62 at 49.

288. Id.

289. National League of Cities v. Usury, 426 U.S. 833 (1976). 
290. Id. at 855 .

291. Id. at 842 .

292. R. Stewart, Pyramids of Sacrifice? Problems of Federalism In Mandating State Implementation of National Energy Policy, 86 Yale L.J. 1257-62 (1977).

293. See p. 55 supra.

294. National League of Cities v. Usury, 426 U.S. 833, 856 (1976)

295. R. Wallick \& W. Montalto, Symbiosis or Domination: Rights and Remedies Under Grant-Type Assistance Programs, 46 Geo. Wash. L. Rev. 159, 166-67 (1978).

296. 42 U.S.C. $\$ 5501$ et seq. (1977 \& Supp. 1978).

297. SH $\Lambda \mathrm{COD}$, supl'a iúle 90 at 97.

298. National Energy Conservation Policy Act of 1978 Pub. L. No. 95-619, $\$ 231,92$ Stat. 3206 (1978).

299. Id. at $\$ 232$.

300. Id. at $\$ 251(b)$.

301. Id. at $\$ \$ 301-302$.

302. Federal Incentives, supra note 95 at 12 .

303. J. Kenkel, Legal Aspects of Financing Certain Public Improvements, 6 Urb. Law. 381-82 (1973).

304. Surlu Clara Study, supra note 46 at $33 \mathrm{nn}$. 330-31.

305. Id. at 33 n. 335 ,

306. Id. at $33-4 \mathrm{nn}$. $346-48$

307. Id. at 33.

308. Id. at $33-34$.

309. See pp. 51-52 supra.

310. SHACOB, supra note 90 at 97; Policy Options, supra note 62 at 131-38.

311. SHACOB, supra note 90 at 97.

312. Federal Incentives, supra note 95 at 10.

313. But it should also be noted that this policy has numerous disadvantages, like the dangerous environmental disorders we now face. 
314. See Policy Options supra note 62 at 16.

315. Policy Options, supra note 62 at 16.

316. Id. at 29.

317. Federal Incentives supra note 95 at 201.

318. 26 U.S.C. $\$ 611-12$ (1967 \& Supp. 1978); Policy Options, supra note 62 at 16.

319. Natural Resource Taxation, supra note 95 at $802-37$.

320. Policy Options, supra note 62 at 31 .

321. 26 U.S.C. $\$ 263(\mathrm{c})(1967$ \& Supp. 1978)

322. Federal Incentives, supra note 95 at 213.

323. Policy Options, supra note 62 at 31 .

324. Id. at $30-31$.

325. Federal Incentives, supra note 95 at 212.

326. Id. at 257.

327. Policy Options, supra note 62 at 33.

328. Federal Incentives, supra note 95 at 257.

329. Id.

330. Policy Options, 'supra note 62 at 34.

331. Federal Incentives, supra note 95 at 240 .

333. Id. at 258.

333. Natural Gas Policy Act of 1978, Pub. L. No. 95-621, 92 Stat. 3350 (1978).

334. Federal Incentives, supra note 95 at 171.

335. Policy Options, supra note 62 at 27.

336. Id. at 28 .

337. Id. at 27.

338. Federal Incentives, supra note 95 at 256.

339. Power Plant and Industrial Fuel Use Act of 1978, Pub. L. No. 95-620, \$\$601-602, 92 Stat. 3289 (1978). 
340. Federal Incentives, supra note 95 at 153; Policy Options, supra note 62 at 25.

341. Federal Incentives, supra note 95 at $255-6$.

342. Id.

343. Id.

344. Id.

345. Id. at 255.

346. Policy Options, supra note 62 at 23 .

347. Id. at 23-24.

348. Federal Incentives, supra note 95 at 255.

349. Id. at 115 .

350. Id. at 255.

351. Id. at 124-28.

352. Id. at 255 .

353. Legal Barriers, supra note 172 at 177.

354. Id. at 178.

355. See generally Home Mortgage Lending, supra note 259 at 14-15.

356. Id. at 15, Legal Barriers, supra note 172 at 180.

357. United States Department of Housing and Urban Development, Interim Performance Criteria for Solar Heating and Combined Heating/Cooling Systems and Dwellings (1977).

358. Constraints and Incentives, supra note 90 at 80.

359. Id. at 77.

360. Home Mortgage Lending, supra note 259 at 12; Constraints and Incentives, supra note 90 at 75.

361. Legal Barriers, supra note 172 at 77.

362. SHACOB, supra note 90 at 127.

363. Id.

364. Home Mortgage Lending, supra note 259 at 7. 
$x^{2}$

365. SHACOB, supra note 90 at 35 .

366. Legal Barriers, supra note 172 at 79.

367. SHACOB, supra note 90 at 124 .

368. Interim Policy Options, supra note 92 at 34.

369. National Energy Conservation Policy Act of 1978, Pub. L. No. 95-619, $\$ \$ 541-545$, 92 Stat. 3206 (1978).

370. Legal Barriers, supra note 172 at 79 n. 15 .

371. SHACOB, supra note 90 at 127.

372. Id. at 128; Constraints and Incentives, supra note 90 at 78.

373. SHACOB, supra note 90 at 128.

374. Policy Options, supra note 62 at 57-58.

375. Constraints and Incentives, supra note 90 at 77.

376. SHACOB, supra note 90 at 116 .

377. See p. 57 supra.

378. National Energy Conservation Policy Act of 1978, Pub. L. No. 95-619 \$\$ 521-524 (1978).

379. Id. at $\$ 523$.

380. Id. at SS 561-569.

381. A. Hirshberg, Public Policy For Solar Heating and Cooling, 32 The Bulletin of the Atomic Scientists no. 8, 41 (1976).

382. Cicero, On the Commonwealth. 


\begin{tabular}{|c|c|c|}
\hline $\begin{array}{c}\text { Document Control } \\
\text { Page }\end{array}$ & $\begin{array}{l}\text { 1. SERI Report No. } \\
\text { TR-62-269 }\end{array}$ & 3. Recipient's Accession No. \\
\hline \multirow{2}{*}{\multicolumn{2}{|c|}{$\begin{array}{l}\text { 4. Title and Subtitle } \\
\text { Legal and Institutional Implications of Providing } \\
\text { Financial Incentives to Encourage the Development of } \\
\text { Solar Technologies }\end{array}$}} & $\begin{array}{l}\text { 5. Publication Date } \\
\text { July } 1979\end{array}$ \\
\hline & & 6. \\
\hline \multicolumn{2}{|l|}{$\begin{array}{l}\text { 7. Author(s) } \\
\text { Richard Hyatt }\end{array}$} & 8. Performing Organization Rept. No. \\
\hline \multirow{2}{*}{\multicolumn{2}{|c|}{$\begin{array}{l}\text { 9. Performing Organization Name and Address } \\
\text { Solar Energy Research Institute } \\
1536 \text { Cole Boulevard } \\
\text { Golden, Colorado } 80401\end{array}$}} & $\begin{array}{l}\text { 10. Project/Task/Work Unit No. } \\
6223.20\end{array}$ \\
\hline & & $\begin{array}{l}\text { 11. Contract (C) or Grant (G) No. } \\
\text { (C) } \\
\text { (G) }\end{array}$ \\
\hline \multirow{2}{*}{\multicolumn{2}{|c|}{ 12. Sponsoring Organization Name and Address }} & $\begin{array}{l}\text { 13. Type of Report \& Period Covered } \\
\text { Technical } \\
\end{array}$ \\
\hline & & 14. \\
\hline
\end{tabular}

15. Supplementary Notes

16. Abstract (Limit: 200 words)

The legal basis to provide financial incentives is found in the enumerated powers of the Constitutions for the exercise of federal authority, the police and tax powers for the exercise of state authority, and state delegated powers for the exercise of local authority. These powers are limited by the federal and state constitutions, and the scope of delegated authority. The major types of financial incentives are tax incentives, including income tax deductions and credits, accelerated depreciation allowances, tax-exempt bonds, and reduction in property and sales taxes; loan incentives, including low interest loans, government guaranteed and insured loans, and elimination of statutory and secondary market constraints; and government transfer incentives, including grants in aid from all levels of government. Other incentives that will indirectly affect the financing and availability of solar energy technologies include eliminating or reducing financial incentives benefiting competitive energy sources, government action to insure the operation of solar energy equipment, government-sponsored education, research, and development programs, government demonstration and procurement programs.

17. Document Anaiysis

a. Descriptors

b. Identifiers/Open-Ended Terms

c. UC Categories

18. Availability Statement

19. No. of Pages

57

20 Price

$\$ 5.25$ 